OPEN ACCESS

Edited by:

Timothy C. Bartholomaus,

University of Idaho, USA

Reviewed by:

Ellyn Mary Enderlin,

University of Maine, USA

Samuel Huckerby Doyle,

Aberystwyth University, UK

*Correspondence:

Emily A. Hill

e.hill3@newcastle.ac.uk

Specialty section This article was submitted to Cryospheric Sciences,

a section of the journal

Frontiers in Earth Science

Received: 05 September 2016 Accepted: 23 December 2016

Published: 10 January 2017

Citation:

Hill EA, Carr JR and Stokes CR (2017) A Review of Recent Changes in Major Marine-Terminating Outlet Glaciers in Northern Greenland.

Front. Earth Sci. 4:111. doi: 10.3389/feart.2016.00111

\section{A Review of Recent Changes in Major Marine-Terminating Outlet Glaciers in Northern Greenland}

\author{
Emily A. Hill ${ }^{1 *}$, J. Rachel Carr ${ }^{1}$ and Chris R. Stokes ${ }^{2}$ \\ ${ }^{1}$ School of Geography, Politics and Sociology, Newcastle University, Newcastle upon Tyne, UK, ${ }^{2}$ Department of Geography, \\ Durham University, Durham, UK
}

Over the past two decades, mass loss from the Greenland Ice Sheet (GrIS) has accelerated and contributed to global sea level rise. This has been partly attributed to dynamic changes in marine terminating outlet glaciers. Outlet glaciers at the northern margin of the ice sheet drain $40 \%$ of its area but are comparatively less well-studied than elsewhere on the ice sheet (e.g., central-west or south-east). In order to improve our understanding of this region of the GrIS, this paper synthesizes previously-published research on 21 major marine terminating outlet glaciers. Over the last 130 years, there has been a clear pattern of glacier retreat, particularly over the last two decades. This was accompanied by velocity increases on the majority of glaciers for which records exist. Despite a distinct signal of retreat, however, there is clear variability within the region, which has complicated efforts to determine the precise drivers of recent changes, such as changes in ice tongue buttressing, atmospheric and/or oceanic warming, in addition to the possibility of glacier surging. Thus, there is an important need for further work to ascertain the precise drivers of glacier change, which is likely to require datasets on recent changes in the ocean-climate system (particularly sub-surface ocean temperatures) and numerical modeling of glacier sensitivity to these various forcings. Objective identification of surge-type glaciers is also required. Given that Northern Greenland is predicted to undergo greater warming due to Arctic Amplification during the twenty-first century, we conclude that the region has the potential to become an increasingly important source of mass loss.

\section{Keywords: cryosphere, marine-terminating outlet glaciers, Greenland Ice Sheet, northern Greenland, Arctic glaciology}

\section{INTRODUCTION}

Mass loss from the Greenland Ice Sheet (GrIS) has doubled in the last two decades (Shepherd et al., 2012) as a result of both increased ice discharge and increased surface melt (van den Broeke et al., 2016). Together, these processes currently contribute $\sim 0.6 \mathrm{~mm}$ per year to global sea level rise (Fürst et al., 2015). The increased ice discharge is associated with marineterminating outlet glaciers that have undergone thinning, retreat and acceleration since the mid1990s (Rignot and Kanagaratnam, 2006; Moon and Joughin, 2008; Joughin et al., 2010a). Their retreat between 2000 and 2010 was considered exceptional over the past half century (Howat and Eddy, 2011), and dynamic discharge from outlet glaciers was thought to be responsible for 
$\sim 40 \%$ of mass loss from the ice sheet between 1991 and 2015 (van den Broeke et al., 2016). The recent rapid outlet glacier retreat and flow acceleration is understood to be in response to ocean-climate forcing (McFadden et al., 2011; Cook et al., 2014). Potential mechanisms by which atmospheric temperatures may promote retreat through glacier calving are the drainage of supraglacial lakes or water-filled crevasses fracturing through the full ice thickness (van der Veen, 2007; Das et al., 2008). Alongside this, ocean warming may increase rates of submarine melting at marine-terminating glaciers (Holland et al., 2008), which may be further enhanced by submarine meltwater plume discharge (Motyka et al., 2003; Jenkins, 2011). In addition, sea ice removal or decline may promote calving and a longer ice-free season may allow greater volumes of ice to be lost during the year (e.g., Carr et al., 2013b, 2014; Moon et al., 2015).

However, the magnitude of individual glacier responses to these forcings is known to be modulated by local topographic factors (Howat et al., 2007; Moon et al., 2012; Carr et al., 2013b). For example, fjord width is a key local control on glacier retreat, where a narrow fjord can delay the removal of icebergs from the terminus (e.g., Warren and Glasser, 1992; Jamieson et al., 2012; Carr et al., 2014). Another important glacierspecific factor is basal topography, whereby a reverse inland bed slope can make a glacier vulnerable to feedbacks between rapid thinning, acceleration and retreat (e.g., Thomas et al., 2009). The relative contribution of external factors (oceanic and climatic) vs. localized glacier-specific factors (most notably fjord geometry and basal topography) remains poorly understood and identifying their respective influence on outlet glacier retreat is of paramount importance for estimating future glacier response to climate change and sea level rise (Nick et al., 2013; Porter et al., 2014; Carr et al., 2015).

Over the last two decades, several areas of the ice sheet have been the focus of regional to local scale studies of glacier change, particularly Jakobshavn Isbræ in west Greenland (Joughin et al., 2008b, 2012; Podrasky et al., 2012), and Kangerdlugssuaq and Helheim Glaciers in south east Greenland (Howat et al., 2007; Joughin et al., 2008a). However, with the possible exception of Petermann Glacier and the northeast Greenland Ice Stream (NEGIS), major outlet glaciers in northern Greenland have received much less attention. This is despite several studies documenting large calving events from northern Greenland ice tongues during the past decade (Moon and Joughin, 2008; Johannessen et al., 2013; Murray et al., 2015), the most notable of which was the $270 \mathrm{~km}^{2}$ retreat of Petermann Glacier's floating tongue in 2010 (Nick et al., 2012; Johannessen et al., 2013). Thus, there is a paucity of data from northern Greenland, compared to other areas. It remains unclear how these glaciers are responding to climate change compared to other areas of Greenland and in the context of their longer-term behavior over the last 100 years. There is also uncertainty about the forcing of glacier retreat (atmospheric vs. oceanic warming) and how these glaciers might respond to future changes at their terminus (such as ice tongue losses) and whether these changes have the potential to trigger substantial inland ice loss and glacier acceleration, similar to that experienced at Jakobshavn Isbræ (Joughin et al., 2004; Amundson et al., 2010), and on the Antarctic Peninsula
(Scambos, 2004). Further complexity in the region arises from surge-dynamics and the literature highlights that several glaciers in this region as potentially surge-type (Mock, 1966; Reeh et al., 1994; Joughin et al., 1996b). We define surges here as the periodic fluctuation between long periods of slow glacier flow (quiescent phase) and short-lived rapid flow, which results in at least an order of magnitude increase (active phase; Meier and Post, 1969; Sharp, 1988). These surge events can be either thermally or hydrologically controlled (Murray et al., 2003) driven by basal temperatures (Fowler et al., 2001) or changes in basal hydrology (Kamb et al., 1985), respectively.

Given that northern Greenland glaciers collectively drain 40\% of the GrIS by area (Rignot and Kanagaratnam, 2006) and consist of large catchments, some grounded well below sea-level up to $100 \mathrm{~s}$ of $\mathrm{km}$ inland (Morlighem et al., 2014), this region has the potential to be a large contributor to future dynamic change, mass loss, and sea level rise.

Here, we review previous research in this region, with a particular focus on recent changes in marine-terminating outlet glaciers and their links to ocean-climate forcing. Our study area is defined by a coastline that is $\sim 2000 \mathrm{~km}$ long (Figure 1). This is drained by around 40 marine-terminating outlet glaciers and we focus on a sample of 21 of these glaciers (Figure 1), which represent the primary ice drainage routes where previous work has been undertaken (Higgins, 1991; Rignot et al., 1997, 2001). Many of these glaciers have large catchments overlying deep basal topography, and exhibit high ice velocities (up to $1200 \mathrm{~m} \mathrm{a}^{-1}$; Joughin et al., 2010a) that are comparable to fastflowing outlets elsewhere on the ice sheet (Figure 2). Thus, they have the potential to be large contributors to dynamic mass loss in the future.

\section{REGIONAL CHANGES IN GLACIER DYNAMICS}

Early scientific explorations of northern Greenland by Peary (1892) and the First (1912) and Second (1916-1918) Thule expeditions led by Rasmussen $(1912,1919)$ sought to improve understanding of the northern margin of the ice sheet. Subsequent studies identified large floating ice tongues, up to $50 \mathrm{~km}$ long, on many northern Greenland glaciers (Koch, 1928; Higgins, 1991). In this respect, they are unique in comparison to other regions of the ice sheet, where floating ice tongues are generally much shorter or absent. Historically, a significant proportion of northern Greenland glaciers are documented to have retreated, particularly between 1894 and 1962 (Davies and Krinsley, 1962). More recently, estimates of ice discharge in the late 1990s indicated widespread thinning (Rignot et al., 1997). Studies by Higgins (1991), Rignot et al. (1997), and Rignot et al. (2001) provided more comprehensive observations of glacier width, length, the presence of floating tongues, as well as initial velocity measurements and grounding line positions. Since then, a comprehensive analysis of northern Greenland glacier retreat and velocity fluctuations has not been conducted, although outlet glaciers from this region are often incorporated into GrIS wide studies (Moon and Joughin, 2008; Joughin et al., 2010a; 


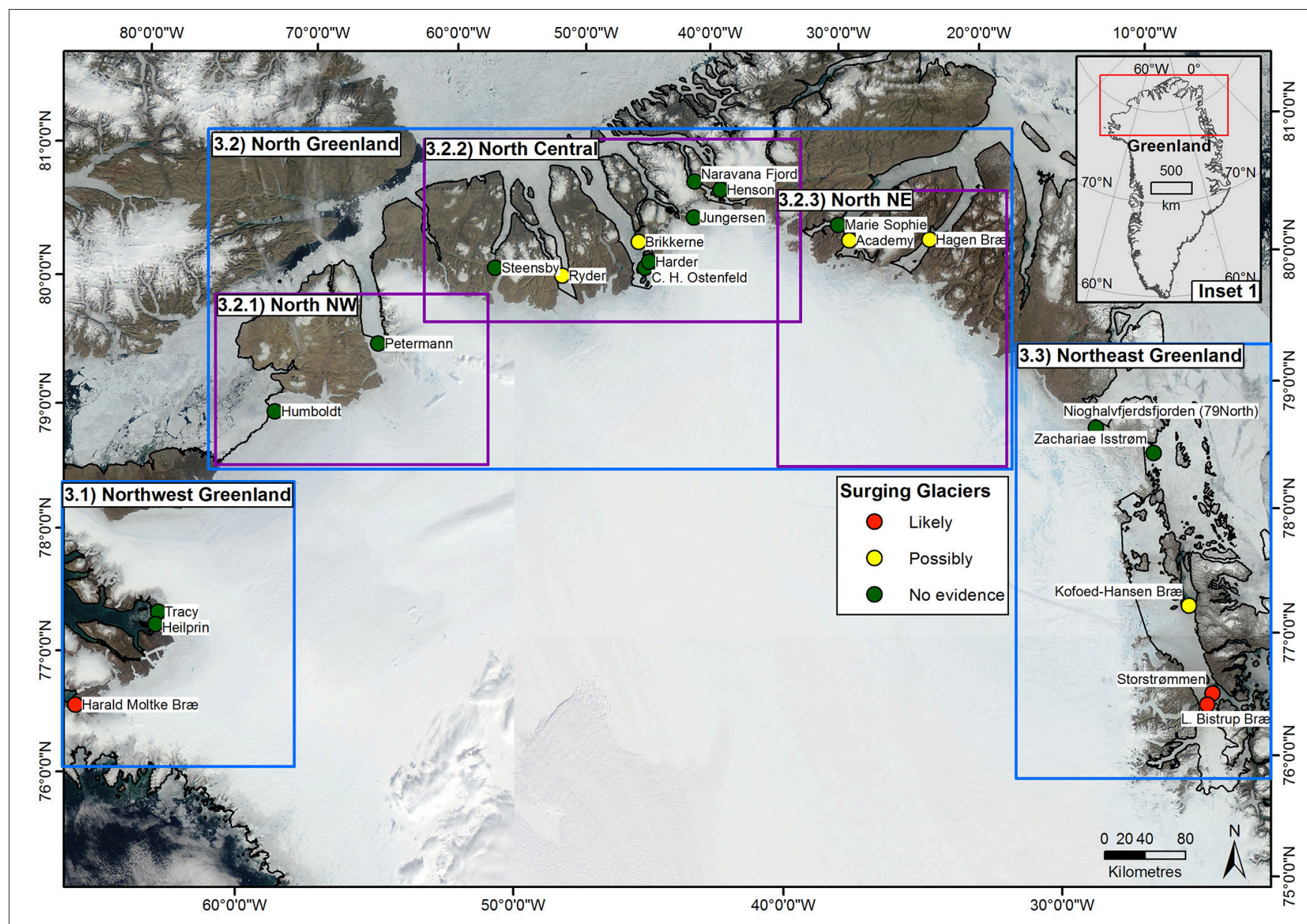

FIGURE 1 | Location map of Northern Greenland showing the glaciers reviewed in this paper. The study area has been split into three geographical regions which are Northwest Greenland (3.1), North Greenland (3.2), and Northeast Greenland (3.3). Within North Greenland there are a further three sub-geographical regions, North NW (3.2.1), North Central (3.2.2), and North NE (3.2.3). Colored circles show a first order classification of potential surge-type glaciers across northern Greenland. Red circles show glaciers which are likely to be surge type based on clear surge-cycles having been recorded within the literature. Yellow circles show glaciers at which surging is possible based on glaciers which may have shown surge-characteristics, but either have not been referred to as surge-type or have not undergone a large surge event. Green circles show glaciers at which no evidence of surging has been recorded in the literature. Background image derived from NASA EOSDIS Worldview (16.07.15 and 21.07.15).

Box and Decker, 2011; Murray et al., 2015). These syntheses reported significant increases in outlet glacier retreat rates across Greenland (for 1992-2006; Moon and Joughin, 2008) and that the largest cumulative area changes (during 2000-2010) occurred in northern Greenland, particularly at glaciers with the largest floating portions (e.g., Petermann, Humboldt, and Zachariae Isstrøm; Box and Decker, 2011).

An outline of the characteristics of each of the outlet glaciers in our study region is provided in Table 1 , which also includes glacier catchment sizes delineated using bedrock topography and ice thickness data (Morlighem et al., 2014) input into the Shreve hydropotential formula (Shreve, 1972) to determine subglacial water routing and thus glacier drainage catchments. The following sections are a synthesis of previous work on each of the glaciers by region (Figure 1), with a focus on describing the key characteristics of each glacier and setting recent observations in a broader historical context. For comparison between subsections, we focus on terminus length changes, but in some cases where length is not reported in the literature, we refer to terminus change as it is reported in area.

\section{Northwest Greenland}

Northwest Greenland (Figure 1), has recently undergone glacier retreat, particularly between 2000 and 2010 (Murray et al., 2015). Most outlets in this region have undergone long-term thinning (1994-2014; Csatho et al., 2014) and have accelerated by $28 \%$ between 2000 and 2010 (Moon et al., 2012). Three of the largest outlet glaciers in the far northwestern region are Harald Moltke Bræ, which drains into Wolstenholme Fjord, and Heilprin and Tracy Glaciers, which terminate in the neighboring Inglefield Bay (Figure 3).

\section{Harald Moltke Bræ}

Harald Moltke Bræ is an outlet glacier in northwest Greenland that is $6.3 \mathrm{~km}$ wide at its grounded terminus (Koch, 1928; Wright, 1939; Davies and Krinsley, 1962; Rignot et al., 2001; 


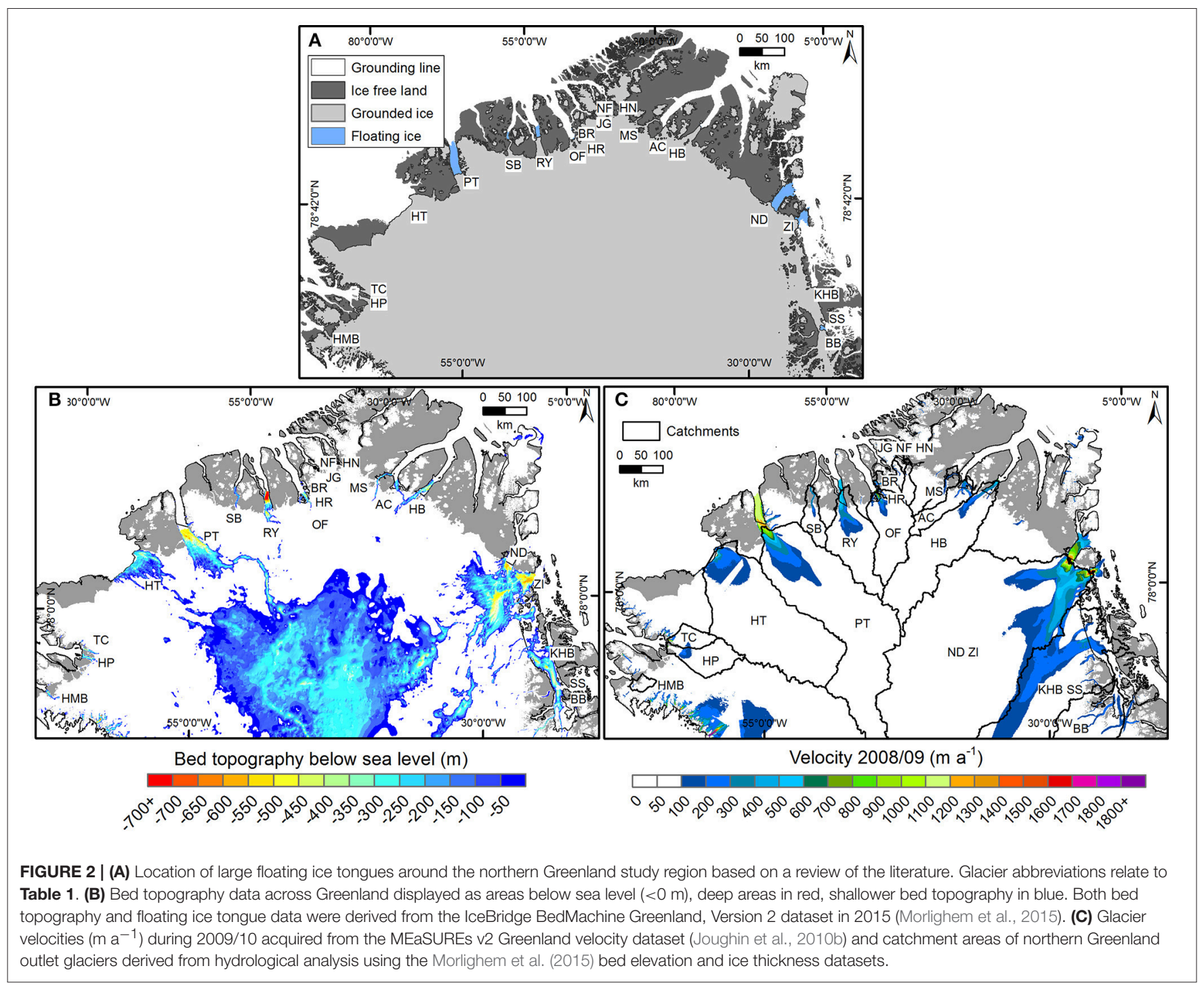

Figure 2). Early observations suggested that the terminus had two calving lobes (Wright, 1939) shown in Figure 3B. However, recent imagery shows this is no longer the case (Figure $3 \mathbf{B}$ ). The catchment area of Harald Moltke Bræ is smaller than most other glaciers in the study area, draining only $1400 \mathrm{~km}^{2}$ (Table 1).

Early studies provided a detailed historical account of terminus change for the period 1916-1965 (Wright, 1939; Davies and Krinsley, 1962; Mock, 1966; Figure 3B). Between 1916 and 1926 the glacier retreated, which was followed by advance until 1932 when it reached a similar position as in 1916 (Wright, 1939; Davies and Krinsley, 1962; Mock, 1966). Between 1932 and 1937, the calving of large tabular icebergs was observed (Wright, 1939) and, by 1959, the terminus had retreated $5.5 \mathrm{~km}$ from its 1932 position (Davies and Krinsley, 1962). It is also known that the glacier underwent net retreat of $2.9 \mathrm{~km}$ between 2000 and 2010 (Murray et al., 2015).

From 1916 to 1965 the velocity of Harald Moltke Bræ fluctuated greatly between 30 and $1000 \mathrm{~m} \mathrm{a}^{-1}$ (Mock, 1966). More recently, in $2000 / 01$, the glacier was flowing at
$30-100 \mathrm{~m} \mathrm{a}^{-1}$ at the terminus, reaching up to a maximum of $300 \mathrm{~m} \mathrm{a}^{-1}$ further up glacier (Joughin et al., 2010a). By 2005, the velocity at the terminus increased to $2000 \mathrm{~m} \mathrm{a}^{-1}$ (Joughin et al., 2010a). Several authors have suggested these recent changes in velocity reflect surge behavior at Harald Moltke Bræ (Rignot and Kanagaratnam, 2006; Moon et al., 2012). In particular, velocity increase during 2005 coincided with terminus advance $(1.2 \mathrm{~km})$ in 2004/2005 (Murray et al., 2015).

Since the detailed work of Mock (1966), few studies have specifically focused on Harald Moltke Bræ. Its surge-like behavior is unusual in comparison to nearby outlet glaciers. Despite showing marked increases in velocity and advance during proposed surge events (Rignot and Kanagaratnam, 2006; Joughin et al., 2010a; Murray et al., 2015), the glacier has undergone large net retreat following surge events (Murray et al., 2015). This has led to a retreat of $\sim 12 \mathrm{~km}$ compared to its position in 1916 (Figure 3B) and hints that the glacier has been influenced by longer-term external environmental drivers. 
TABLE 1 | Key data on the 21 Northern Greenland glaciers reviewed in this paper.

\begin{tabular}{|c|c|c|c|c|c|c|c|c|c|}
\hline Code & Glacier & Region & $\begin{array}{c}\text { Width } \\
\text { (km) }\end{array}$ & $\begin{array}{c}\text { Floating ice } \\
\text { tongue length } \\
\text { (km) }\end{array}$ & $\begin{array}{c}\text { Drainage } \\
\text { area }\left(\mathbf{k m}^{2}\right)\end{array}$ & $\begin{array}{c}\text { Area of } \\
\text { northern } \\
\text { GrIS (\%) }\end{array}$ & $\begin{array}{l}\text { Area of } \\
\text { GrIS (\%) }\end{array}$ & $\begin{array}{c}\text { Ice discharge } \\
\left(\mathrm{km}^{3} \mathrm{a}^{-1}\right)\end{array}$ & Surge-type \\
\hline \multicolumn{10}{|c|}{ NORTHWEST GREENLAND } \\
\hline $\mathrm{HMB}$ & Harold Moltke Bræ & NW & 6.3 & - & 1401 & 0.28 & 0.12 & - & Likely \\
\hline HP & Heilprin & NW & 6.7 & - & 8408 & 1.66 & 0.70 & $2.19^{a}$ & No evidence \\
\hline TC & Tracy & NW & 5.0 & - & 3835 & 0.76 & 0.32 & $1.43^{\mathrm{a}}$ & No evidence \\
\hline \multicolumn{10}{|c|}{ NORTH GREENLAND } \\
\hline HT & Humboldt & $\mathrm{N}-\mathrm{NW}$ & 91 & - & 56,357 & 11.16 & 4.66 & $6.25^{a}$ & No evidence \\
\hline PT & Petermann & $\mathrm{N}-\mathrm{NW}$ & 21 & 48 & 71,305 & 14.11 & 5.90 & $12.82^{\mathrm{a}}$ & No evidence \\
\hline SB & Steensby & $\mathrm{N}-\mathrm{C}$ & 4.8 & 5.1 & 4694 & 0.93 & 0.39 & $0.63^{b}$ & No evidence \\
\hline $\mathrm{RY}$ & Ryder & $\mathrm{N}-\mathrm{C}$ & 10 & 26 & 17,265 & 3.42 & 1.43 & $3.88^{a}$ & Possibly \\
\hline OF & C. H. Ostenfeld & $\mathrm{N}-\mathrm{C}$ & 7.9 & 1.5 & 14,494 & 2.87 & 1.20 & $2.32^{\mathrm{a}}$ & No evidence \\
\hline $\mathrm{HR}$ & Harder & $\mathrm{N}-\mathrm{C}$ & 5.1 & - & 726 & 0.14 & 0.06 & $0.34^{b}$ & No evidence \\
\hline $\mathrm{BR}$ & Brikkerne & $\mathrm{N}-\mathrm{C}$ & 6.1 & 1.2 & 2058 & 0.41 & 0.17 & $0.44^{b}$ & Likely \\
\hline$J G$ & Jungersen & $\mathrm{N}-\mathrm{C}$ & 2.0 & - & 993 & 0.20 & 0.08 & $0.20^{b}$ & No evidence \\
\hline NF & Naravana Fjord & $\mathrm{N}-\mathrm{C}$ & 2.5 & - & 676 & 0.13 & 0.06 & $0.02^{b}$ & No evidence \\
\hline $\mathrm{HN}$ & Henson & $\mathrm{N}-\mathrm{C}$ & 2.7 & - & 1975 & 0.39 & 0.16 & $0.08^{b}$ & No evidence \\
\hline MS & Marie Sophie & $\mathrm{N}-\mathrm{NE}$ & 3.9 & - & 2565 & 0.51 & 0.21 & $0.02^{b}$ & No evidence \\
\hline$A C$ & Academy & $\mathrm{N}-\mathrm{NE}$ & 8.4 & - & 6184 & 1.22 & 0.51 & $0.69^{a}$ & Possibly \\
\hline $\mathrm{HB}$ & Hagen Bræ & $\mathrm{N}-\mathrm{NE}$ & 9.4 & 0.5 & 30,741 & 6.08 & 2.54 & $1.03^{\mathrm{a}}$ & Possibly \\
\hline \multicolumn{10}{|c|}{ NORTHEAST GREENLAND } \\
\hline ND & Nioghalvfjerdsfjorden & NE & 24 & 69 & 145,562 & 28.81 & 12.04 & $14.27^{\mathrm{a}}$ & No evidence \\
\hline ZI & Zachariae Isstrøm & $\mathrm{NE}$ & 27 & - & & & & $11.65^{\mathrm{a}}$ & No evidence \\
\hline $\mathrm{KHB}$ & Kofoed-Hansen Bræ & NE & 10 & - & 116,440 & 23.05 & 9.63 & & Possibly \\
\hline SS & Storstrømmen & $\mathrm{NE}$ & 12 & 8.4 & & & & $5.80^{\mathrm{a}}$ & Likely \\
\hline BB & L. Bistrup Bræ & NE & 11 & 6.2 & 19,525 & 3.86 & 1.61 & - & Likely \\
\hline
\end{tabular}

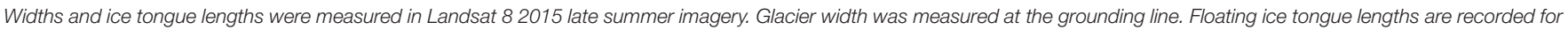

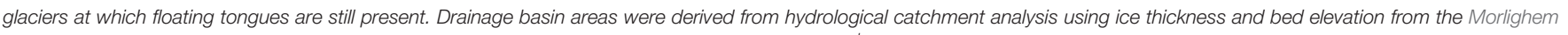

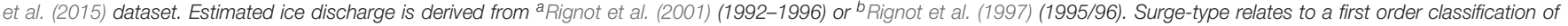
surge-type glaciers in northern Greenland (see also Figure 1).

\section{Heilprin and Tracy Glaciers}

Heilprin and Tracy Glaciers are two large outlet glaciers in northwest Greenland that are 6.7 and $5 \mathrm{~km}$ wide, respectively (Table 1), and collectively drain an area of $\sim 12,000 \mathrm{~km}^{2}$ into Inglefield Bay (Figure 3A). Davies and Krinsley (1962) noted that both glaciers had floating ice tongues in 1892, although early observations with limited data make this difficult to verify. Rignot et al. (2001) later found floating sections absent from both glaciers, which recent grounding line data confirms (Morlighem et al., 2014; Figure 2A). Basal topographic data from these glaciers (Figure 2B), shows they both lie below sea level for a distance of $36-42 \mathrm{~km}$ inland of the terminus (Morlighem et al., 2014).

Both Heilprin and Tracy Glaciers have undergone net retreat in the twentieth Century (Kollmeyer, 1980). Tracy Glacier retreated by $7 \mathrm{~km}$ between 1892 and 1959 (Davies and Krinsley, 1962) and between 1949 and 2009 the glacier retreated a further $15 \mathrm{~km}$ away from Josephine Peary Øer Island (Figure 3C; Dawes and van As, 2010). In contrast, Heilprin Glacier, retreated only $4 \mathrm{~km}$ between 1892 and 2009 (Porter et al., 2014). The retreat of Tracy Glacier has increased over the last two decades: between 2000 and 2005, Tracy Glacier lost $8 \mathrm{~km}$ of its terminus (Figures $\mathbf{4 A}, \mathbf{B}$ ) followed by $2 \mathrm{~km}$ retreat between
2005 and 2013 (Porter et al., 2014). These differing rates of retreat were attributed at least partly to fjord geometry, and primarily deeper basal topography below Tracy Glacier which could allow warm water intrusion (Porter et al., 2014). Surprisingly, despite an inland-sloping bed at Heilprin, it is undergoing slower dynamic change than Tracy Glacier (Porter et al., 2014).

Estimates of ice discharge from European Remote Sensing (ERS) data in the mid-1990s at these glaciers are given in Table 1. Porter et al. (2014) recorded a doubling in thinning rates between 2011 and 2012 at Tracy Glacier. In terms of ice velocity fluctuations, both Heilprin and Tracy Glaciers experienced increases in speed between 2000/01 and 2005/06 of 20 and 40\%, respectively (Joughin et al., 2010a), and coincided with the large retreat observed at Tracy Glacier (Figure 4). There is no record of surging at these glaciers.

Despite retreat taking place at both glaciers, and aside from study by Porter et al. (2014), Tracy and Heilprin Glaciers have been subject to little in-depth research in comparison to other northern Greenland areas. The differing responses of these neighboring glaciers, potentially attributed to fjord geometry, suggests uncertainty remains regarding the controls on these outlet glaciers. 

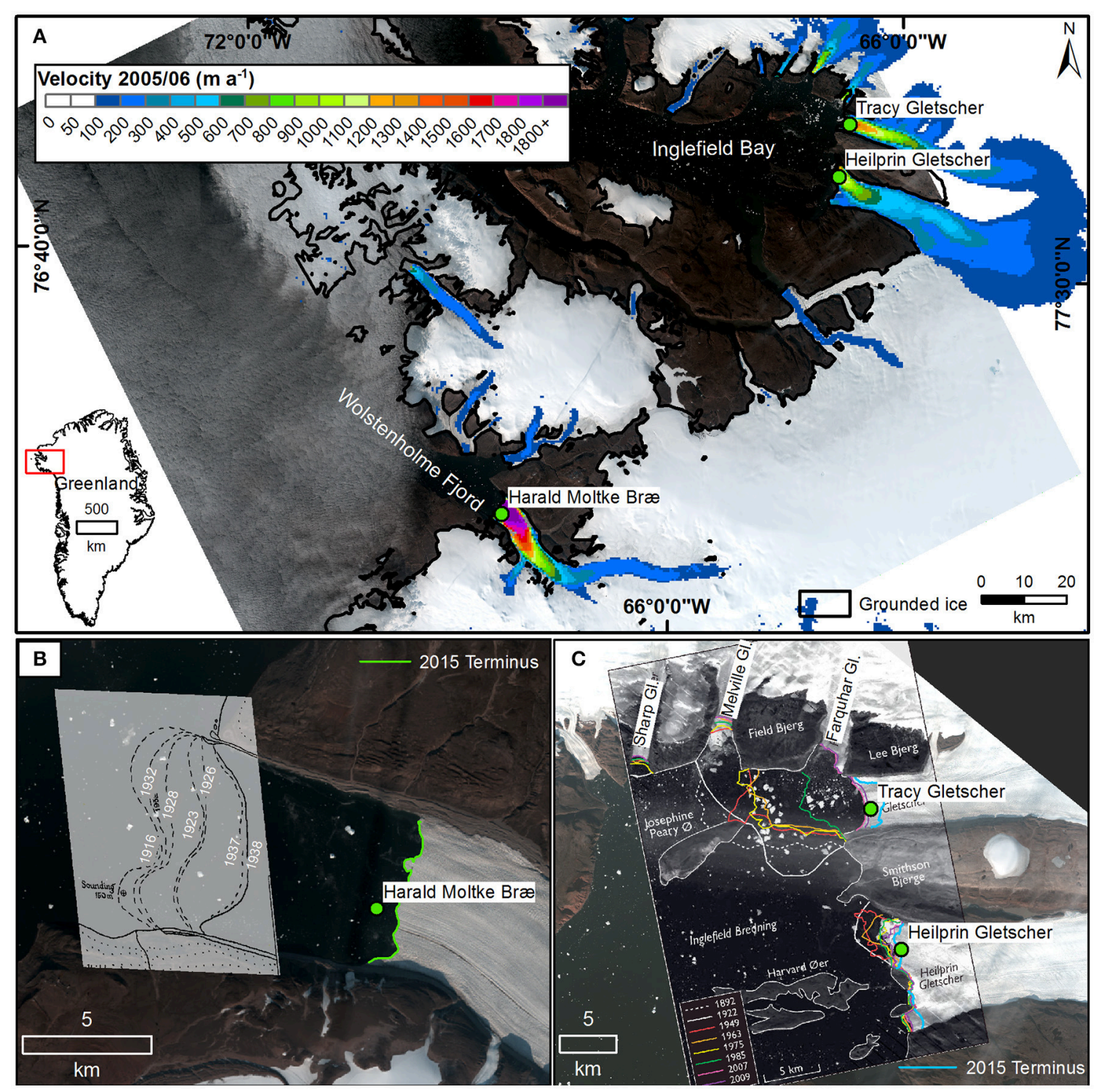

FIGURE 3 | (A) Location of studied glaciers in Northwest Greenland, including Harald Moltke Bræ, Heilprin, and Tracy Glaciers (green circles) and grounded ice (black line). Velocity data were acquired from the 2005/2006 MEaSUREs v2 Greenland velocity (Joughin et al., 2010b). Background imagery is from Landsat 8 (late summer 2015). (B) Estimated terminus positions from Wright (1939), showing changes between 1916 and 1932 , and its position in 2015 (green). (C) Previous terminus positions for Tracy and Heilprin Glaciers (Dawes and van As, 2010) and the 2015 position (light blue).

\section{North Greenland}

The northern sub-region extends from Humboldt Glacier $\left(79^{\circ} 22^{\prime} \mathrm{N}, 64^{\circ} 57^{\prime} \mathrm{W}\right)$ to Hagen Bræ $\left(81^{\circ} 17^{\prime} \mathrm{N}, 28^{\circ} 30^{\prime} \mathrm{W}\right.$; Figure 1) and contains 13 outlet glaciers. A further three sub-regions (North NW, North Central, and North NE) within North Greenland (Figure 1) form the following sections.

\section{North NW}

The north NW region (Figure 1) consists of two of the largest outlet glaciers in Greenland: Petermann and Humboldt. These glaciers have received the most recent research attention in northern Greenland.

\section{Humboldt glacier}

Humboldt Glacier drains $\sim 5 \%$ of the GrIS by area (Rignot and Kanagaratnam, 2006) and has a $\sim 91 \mathrm{~km}$ wide calving front (Table 1), making it the widest outlet glacier in Greenland. The majority of the terminus is thought to be grounded (Higgins, 1989; Joughin et al., 1999), but the northern bay possesses a floating section (Rignot et al., 2001; Carr et al., 2015). The glacier terminus rests significantly below sea level, extending $\sim 100 \mathrm{~km}$ distance inland (Figure 2B).

Early work by Davies and Krinsley (1962) using early expedition maps (Koch, 1928), suggested that the frontal position changed little between 1922 and 1960. A more recent synthesis 

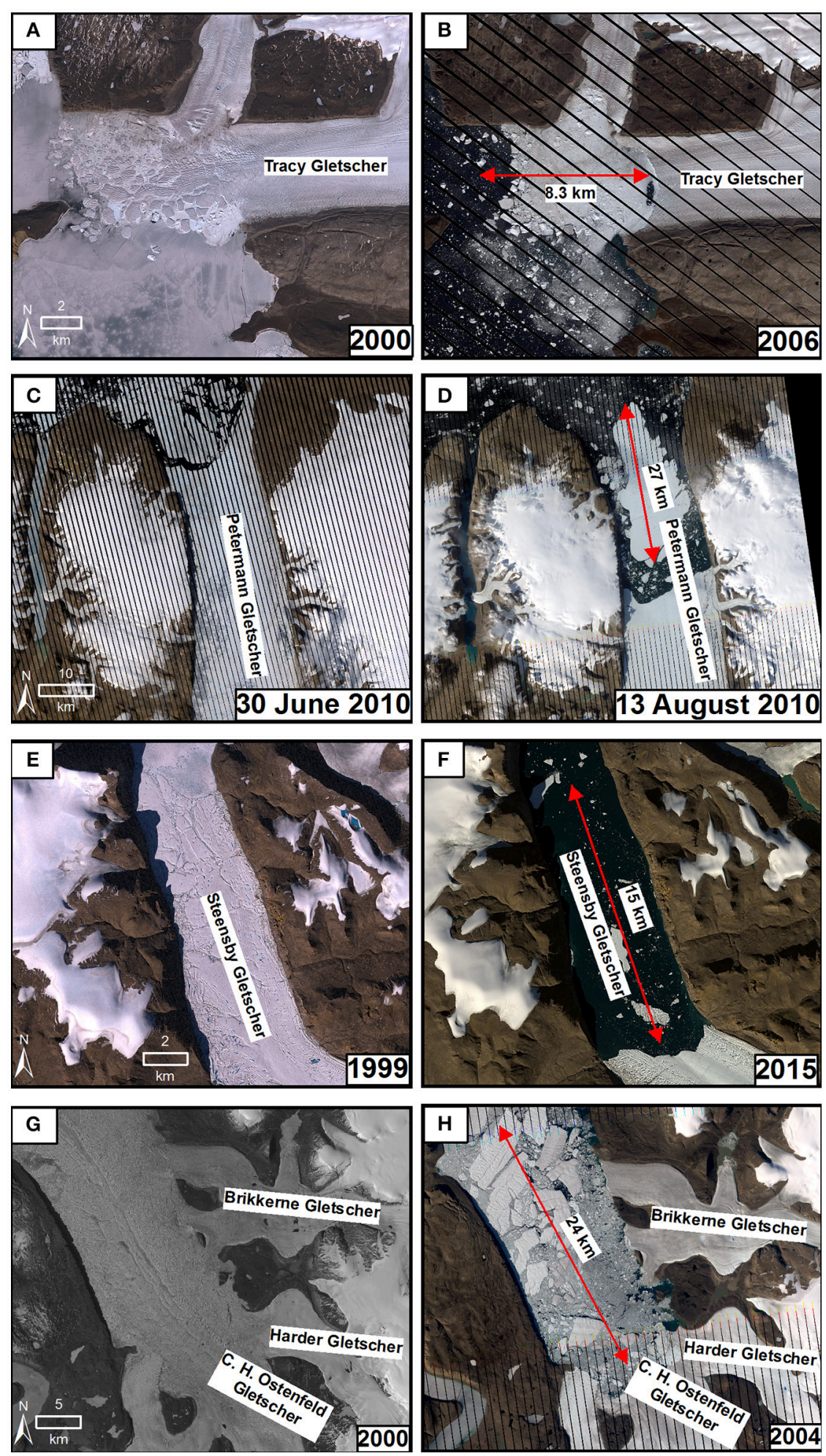

FIGURE 4 | Several dramatic retreat events observed at northern Greenland outlet glaciers. Panels (A,B) show Tracy Glacier retreat between 2000 and 2006. Petermann Glacier's large calving event in 2010 is shown in panels (C/D). Steensby Glacier retreat in panels (E/F). A significant disintegration of C. H. Ostenfeld floating ice tongue is shown in panels $(\mathbf{G} / \mathbf{H})$. All background Landsat imagery was derived from USGS Earth Explorer from the years shown in the panels. 
of 2000-2010 calving positions with results from Rignot et al. (2001), concluded that Humboldt Glacier has been retreating since the 1990s (Box and Decker, 2011). Carr et al. (2015) confirmed accelerated retreat since 1999. Between 2000 and 2010, Humboldt Glacier underwent the largest area change $\left(-311 \mathrm{~km}^{2}\right)$ of the 39 glaciers studied in Box and Decker (2011) ice sheet wide dataset.

Several studies have identified differences between the northern and southern sections of Humboldt Glacier's terminus. Ice flow velocities vary spatially across the glacier front (Rignot et al., 2001; Carr et al., 2015), with up to four times faster flow, and increased glacier thinning in the north section compared to the south (Joughin et al., 1996a; Abdalati et al., 2001; Rignot et al., 2001; Figure 5A). Joughin et al. (1996a) first hypothesized that this was due to a bedrock channel beneath this northern section and later work by Carr et al. (2015) confirmed the presence of a large deep basal trough $(>300 \mathrm{~m})$ that extends $72 \mathrm{~km}$ into the ice sheet interior (Figure 2B).

Recent modeling suggests that both reduced seaice buttressing, particularly in the northern sector, and enhanced meltwater availability derived from increased surface temperatures are responsible for the recent retreat of Humboldt Glacier's terminus (Carr et al., 2015). Observations and modeling also suggest regional differences in glacier response to external forcing may occur along the calving front, largely controlled by underlying topography (Rignot et al., 2001; Carr et al., 2015). This glacier is significant in terms of its wide terminus and catchment area. It is hypothesized that if it retreats past a potential pinning point, which is located close to the northern portion of the terminus, into a deep trough extending $\sim 70 \mathrm{~km}$ inland, rapid retreat and acceleration and subsequent increased mass loss may be expected in future (Carr et al., 2015). Thus, Humboldt Glacier may be particularly susceptible to external forcing.

\section{Petermann glacier}

Petermann Glacier was first documented during the US Polaris Expedition by Hall in 1871 (Kollmeyer, 1980) and has since become one of the most studied glaciers in northern Greenland (Johannessen et al., 2013). Its terminus is $\sim 21 \mathrm{~km}$ wide at the grounding line (Table 1), narrowing down-fjord to between 15 and $20 \mathrm{~km}$ at the current floating terminus (Rignot, 1996; Johannessen et al., 2013; Figure 5A). It's floating ice tongue is one of the most extensive in northern Greenland, previously up to $70 \mathrm{~km}$ long (Rignot et al., 2001; Nick et al., 2012), and now $48 \mathrm{~km}$ in length (Table 1).

The glacier drains $\sim 6 \%$ of the GrIS by area into Hall Basin (Rignot and Kanagaratnam, 2006; Table 1). Large sections of this catchment are grounded well below sea level (Rignot and Steffen, 2008; Johnson et al., 2011), and a deep subglacial trough extends far $(100 \mathrm{~km})$ into the ice sheet interior (Morlighem et al., 2014). The trough is $\sim 200$ to $400 \mathrm{~m}$ deep and coincides with the fastest ice flow (Joughin et al., 1999; Figure 2).

At the grounding line the ice is $\sim 600 \mathrm{~m}$ thick (Johannessen et al., 2013), thinning considerably to $200 \mathrm{~m}$ toward the ice tongue's terminus (Falkner et al., 2011). There are large differences in estimated ice discharge, depending on whether calculations are made at the glacier front (Higgins, 1991) or the grounding line (Rignot et al., 1997). Estimates at the grounding line, give a value of $13.2 \mathrm{~km}^{3} \mathrm{a}^{-1}$ (Rignot et al. (1997), much higher than estimated calving fluxes at the glacier terminus $(0.59$ $\mathrm{km}^{3} \mathrm{a}^{-1}$; Higgins, 1991). These different estimates are likely to be due to increasing rates of mass loss through extreme melting beneath the floating ice tongue (Rignot et al., 1997). However, it could also be in part attributed to different measurement accuracy between using aerial photographs (Higgins, 1991) and radar satellite imagery accompanied by digital elevation models (Rignot et al., 1997).

The majority of mass loss (80\%) at Petermann is via high rates of submarine melting beneath the floating ice tongue (Rignot et al., 2001; Rignot and Steffen, 2008). This explains relatively low iceberg calving rates (Higgins, 1991), despite its large grounding line flux (Rignot et al., 1997; Reeh et al., 1999). Melt rates vary spatially beneath the ice tongue, from $0 \mathrm{~m} \mathrm{a}^{-1}$ at the grounding line, to a peak of $25 \mathrm{~m} \mathrm{a}^{-1}$ at $10 \mathrm{~km}$ downstream of the grounding line (Rignot and Steffen, 2008). Ocean heat transported into the fjord is likely to account for these high rates of submarine melt (Johnson et al., 2011). Rignot and Steffen (2008) also observed several channels on the underside of the tongue, aligned in the direction of ice flow, which are believed to have formed from submarine melt and warm ocean water having been transported beneath the ice. Recently, it has been suggested that ice thinning in these channels may have weakened the ice shelf and been a precursor to recent calving events in 2010 and 2012 (Münchow et al., 2014).

Terminus retreat normally occurs via the calving of large, tabular icebergs (Johnson et al., 2011), and early studies observed sporadic calving of tabular icebergs up to $50 \mathrm{~m}$ thick and up to $120 \mathrm{~km}^{2}$ (Dunbar, 1978; Kollmeyer, 1980). The frontal position of Petermann remained relatively stationary between 1876 (Koch, 1928; Davies and Krinsley, 1962) and the 1980s, which suggests that iceberg calving is an important component of the longerterm mass balance of the glacier as opposed to solely losing mass via submarine melt (Higgins, 1989). A large calving event took place in August 2010 and attracted substantial scientific attention due to its size (Box and Decker, 2011; Falkner et al., 2011; Nick et al., 2012; Johannessen et al., 2013). This event removed 25\% of the glacier tongue by area (Falkner et al., 2011), creating a tabular iceberg $\sim 27 \mathrm{~km}$ in length and $270 \mathrm{~km}^{2}$ in area (Johannessen et al., 2013; Figures 4C,D). This was followed by another large retreat in 2012 of $10 \mathrm{~km}\left(\sim 130 \mathrm{~km}^{2}\right.$ in area; Johannessen et al., 2013). To put these events into context, Johannessen et al. (2013) found that five major calving events occurred over the past 50 years. A particularly large event occurred in $1991\left(153 \mathrm{~km}^{2}\right)$, but the magnitude of the 2010 event exceeds all others in this 50 year record (Johannessen et al., 2013). Alongside observed terminus changes, grounding line retreat of $450 \mathrm{~m}$ was observed between 1992 and 1996 (Rignot et al., 2001). Future grounding line retreat could allow warm water to be transported greater distances inland, enhancing submarine melt and increasing the instability of Petermann Glacier (Nick et al., 2012). That said, large uncertainty remains over whether large calving events in recent years were part of a natural cycle or in response to climate-induced forcing (Johannessen et al., 2013). 

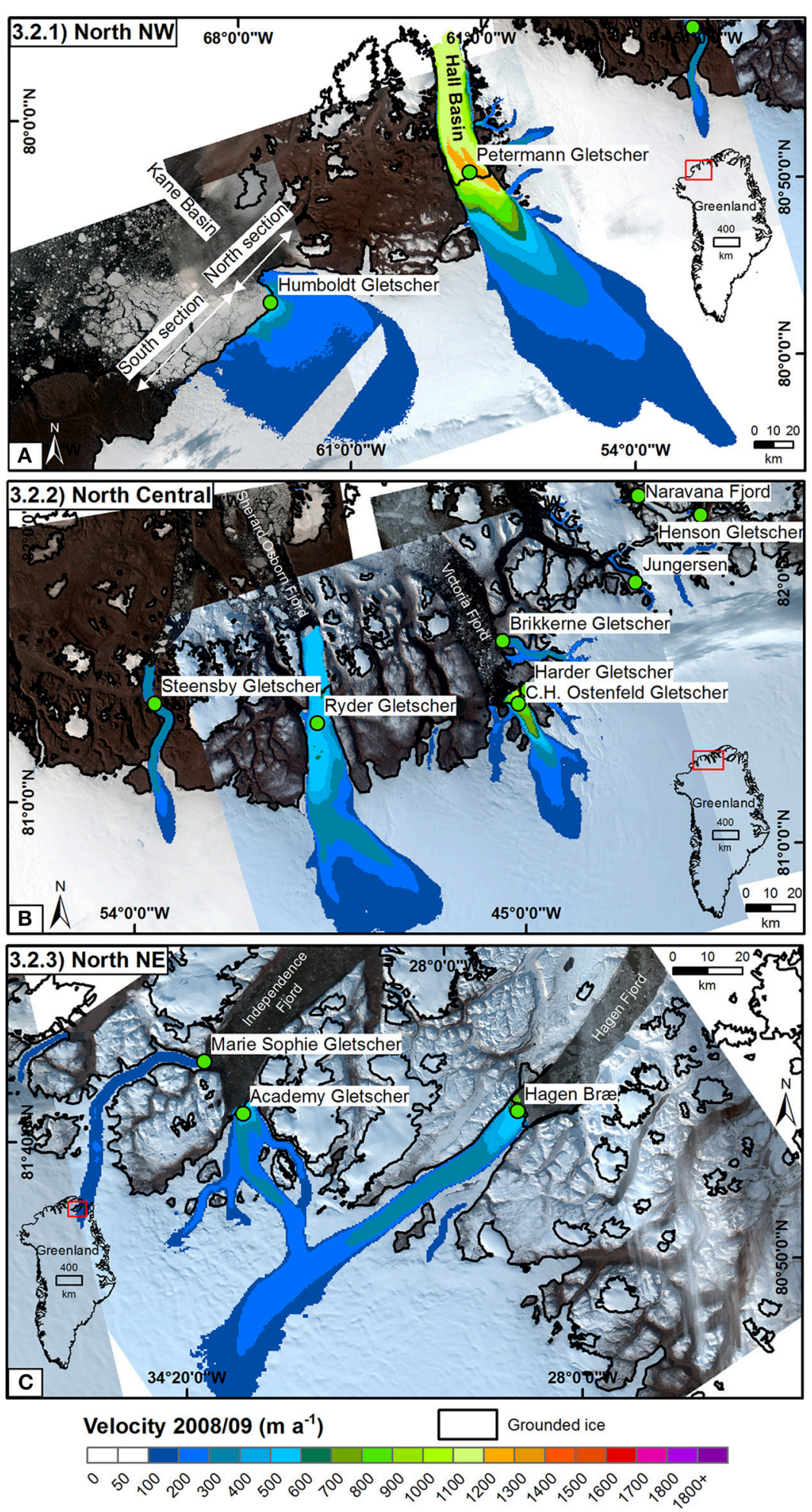

FIGURE 5 | North Greenland region. (A) Sub-region North NW including Humboldt and Petermann. (B) Sub-region North Central including eight outlet glaciers between Steensby Glacier and Henson Glacier. (C) Sub-region North NE, including Marie-Sophie, Academy and Hagen Bræ. Grounded ice is shown in a black outline. Velocity is shown on each glacier in $\mathrm{m} \mathrm{a}^{-1}$. Velocity data was acquired from the 2008/2009 MEaSUREs v2 Greenland velocity (Joughin et al., 2010b). Background imagery is from Landsat 8 (late summer 2015). 
This glacier is one of the fastest flowing outlets in northern Greenland, with velocities of $1000 \mathrm{~m} \mathrm{a}^{-1}$ close to the grounding line (Johnson et al., 2011; Nick et al., 2012; Johannessen et al., 2013; see Figure 5A). However, mean annual velocity has changed little since early estimates (950 $\mathrm{m} \mathrm{a}^{-1}$; Higgins, 1991), and has been relatively stable over recent decades (1985-2011; Rignot and Steffen, 2008; Johannessen et al., 2013). Following the 2010 calving event, only marginal acceleration was observed at the glacier terminus, which could be due to weak attachment of the floating ice tongue to the fjord walls, and suggests that glacier velocities may be largely insensitive to ice tongue retreat (Nick et al., 2012). Warm ocean water, accompanied by the absence of sea ice in Hall Basin prior to the 2010 calving event could be responsible for the magnitude of the 2010 calving event (Johannessen et al., 2013).

In summary, Petermann Glacier is one of the major outlets in Greenland and has lost large portions of its floating tongue over the last two decades. The occurrence of several large calving events over the last 50 years suggest these recent changes may be part of a natural cycle (Nick et al., 2012; Johannessen et al., 2013). However, the terminus now resides at its furthest position inland since 1953 (Johannessen et al., 2013). This retreat is likely due to increased submarine melt under the floating portion of its terminus as a result of recent ocean warming (Nick et al., 2012).

\section{North Central Greenland}

The northernmost region of Greenland in our study (North Central, Figure 1) consists of eight marine-terminating outlet glaciers. The region was first documented in studies by early explorers (Peary, 1892; Rasmussen, 1919), but the majority of these glaciers have had little scientific attention in recent years.

\section{Steensby Glacier}

Steensby Glacier is a $4.8 \mathrm{~km}$ wide glacier that has a catchment area of $4700 \mathrm{~km}^{2}$ and has a $5.1 \mathrm{~km}$ long floating tongue (Table 1). Previous observations suggested this floating ice tongue was formerly between 48 and $62 \mathrm{~km}$ long (Ahnert, 1963). Some of the first observations were made by Ahnert (1963) and terminus changes were later recorded by Higgins (1991). Aerial photographs in 1947 showed the terminus to be floating (Ahnert, 1963), and later oblique photographs from 1953 suggested that it advanced between 1947 and 1953 (Higgins, 1991). By 1996, the grounding line had advanced slightly, and the glacier thickened between these two studies (Rignot et al., 2001). Grounding line data between 1993 and 2013 (Morlighem et al., 2014) showed a more extensive, $16 \mathrm{~km}$-long floating tongue at Steensby Glacier (Figure 2A). However, recent satellite imagery shows $15 \mathrm{~km}$ of retreat between 1999 and 2015 (Figures 4E,F).

Few records of ice velocities at Steensby Glacier exist. Ice velocities showed little fluctuation between estimates made in the 1970s (430 $\mathrm{m} \mathrm{a}^{-1}$ : (Higgins, 1991)) and in 1996 (Rignot et al., 2001). More recently, velocities decreased by $10-15 \%$ between 2000/01 and 2005/06 (Joughin et al., 2010a). Steensby Glacier has often been absent from regional to ice-sheet-wide studies of glacier retreat and flow acceleration, despite having retreated a substantial $1 \mathrm{~km} \mathrm{a}^{-1}$ over the last 15 years (Figures 4E,F).

\section{Ryder Glacier}

Ryder Glacier is a $10 \mathrm{~km}$ wide outlet glacier that drains $\sim 3.5 \%$ of the ice sheet by area (Table 1) into Sherard Osborn Fjord (Figure 5B). The glacier comprises two tributaries that combine at $1000 \mathrm{~m}$ elevation (Joughin et al., 1996b, 1999), and it currently has a $29 \mathrm{~km}$ long floating tongue (Table 1). An early estimate (1978) of discharge at the terminus was $0.66 \mathrm{~km}^{3} \mathrm{a}^{-1}$, making it one of the more important northern Greenland glaciers (Higgins, 1991). Later work found a substantially larger grounding line flux of $3.88 \mathrm{~km}^{3} \mathrm{a}^{-1}$, confirming its high discharge (Rignot et al. (2001).

Relatively few records of terminus change are available for Ryder Glacier. Some of the first observations, from 1917, suggested that the floating tongue extended further north than at present (Koch, 1928), but then retreated by $5 \mathrm{~km}$ between 1947 and 1956 (Davies and Krinsley, 1962). The position of the grounding line also showed retreat during 1992-1996, along with $4 \mathrm{~m} \mathrm{a}^{-1}$ of ice surface thinning (Rignot et al., 2001). Following this period, the glacier thinned by $2-4 \mathrm{~m} \mathrm{a}^{-1}$ between 1997 and 1999 (Abdalati et al., 2001). More recent observations of terminus change are limited, although Murray et al. (2015) documented $0.43-0.55 \mathrm{~km} \mathrm{a}^{-1}$ of glacier advance between 2002 and 2006, followed by a substantial retreat of $3 \mathrm{~km}$ in 2006/07. This was followed by advance during 2007-2010 (Box and Decker, 2011). Should observed thinning continue at Ryder Glacier, large areas of ice may become ungrounded (Thomas et al., 2009; Csatho et al., 2014) making it more susceptible to retreat and further large ice losses. Recent work by Joughin et al. (2010a), however, found no notable changes in velocity at Ryder Glacier between the winters of 2000/01 and 2005/06, with flow speeds similar to those of earlier studies (Joughin et al., 1999; Rignot et al., 2001).

The majority of reported velocity changes recorded at Ryder Glacier focused on a postulated mini-surge event in 1995 during which velocity increased three-fold (Joughin et al., 1996b, 1999). This suggested event occurred between September and October 1995, when ice velocity in the slower upstream areas of the glacier was recorded to have increased from 20 to $150 \mathrm{~m} \mathrm{a}^{-1}$ and then returned to normal in just a 7-week period (Joughin et al., 1996b). However, as velocity change for the faster main trunk of the glacier was not available during this period, uncertainty remains as to the true magnitude of this mini-surge. It was also unclear if the glacier simultaneously advanced during this interval (Joughin et al., 1996b, 1999; Rignot et al., 2001), although it was hypothesized that this acceleration may have caused a substantial increase in ice discharge (Joughin et al., 1996b; Abdalati et al., 2001). Whether this "mini-surge" reflects true surge-behavior at Ryder Glacier is ambiguous and is discussed in more detail in Section Glacier Surging.

\section{H. Ostenfeld Glacier}

C. H. Ostenfeld Glacier is $\sim 7.9 \mathrm{~km}$ wide (Table 1) and has a drainage area of $\sim 14,000 \mathrm{~km}^{2}$. Of the three outlet glaciers draining into Victoria Fjord, it is the largest and has the highest ice discharge (Higgins, 1989; Rignot et al., 2001; Figure 5B).

Limited information is available on past terminus changes at C. H. Ostenfeld Glacier. Over the past two decades, the terminus shows variable periods of advance and retreat (Box and Decker, 
2011; Murray et al., 2015). The floating glacier tongue previously extended $\sim 25 \mathrm{~km}$ down fjord of the grounding line (Higgins, 1989, 1991). It still has a floating ice tongue, but it is now only $1.5 \mathrm{~km}$ long (Table 1). During 1992-1996, the grounding line retreated $500 \pm 200 \mathrm{~m}$ (Rignot et al., 2001). More recently, an advance of $5.6 \mathrm{~km}^{2}$ occurred in 2001/02, followed by an annual retreat of $20.6 \mathrm{~km}^{2}$ in 2002/03 (Box and Decker, 2011). Between the years 2000 and 2006, the majority of the ice tongue disintegrated (Figures 4G,H), removing an estimated total area of $350 \mathrm{~km}^{2}$ (Moon and Joughin, 2008). Following this, a further $1.2 \mathrm{~km}$ retreat occurred (2006-2007; Murray et al., 2015).

Ice velocities have shown little increase between 2000/01 and 2005/06 (Joughin et al., 2010a) and were consistent with earlier velocity values from 1978 and the 1990s of around $800 \mathrm{~m} \mathrm{a}^{-1}$ (Higgins, 1989, 1991; Rignot et al., 2001). Consequently, ice tongue collapse appeared not to significantly affect up-glacier ice velocities during 2000-2006. This could be due to its fragmented nature (Figure 4G), which would provide little resistive stress to the grounded inland ice. There are no documented surges at C. H. Ostenfeld Glacier although a large advance followed by retreat between 2000 and 2003 could suggest surge activity, but this remains untested.

C. H. Ostenfeld is one of the main outlet glaciers in northern Greenland. A large area of its floating tongue has been lost over the past two decades, yet ice velocities have changed little. However, it has recently lost the majority of its floating ice tongue and it may soon retreat back to become grounded, and then discharge grounded ice into the ocean. Thus, there is potential for enhanced velocities and ice discharge from the C. H. Ostenfeld catchment in the near-future, but large uncertainty remains on the glacier's current and future behavior.

\section{Harder and Brikkerne Glaciers}

Harder and Brikkerne are two outlet glaciers also draining into Victoria fjord (Figure 5B) which are 5.1 and $6.1 \mathrm{~km}$ wide, respectively (Table 1). Collectively, they drain an area of $\sim 3000$ $\mathrm{km}^{2}$ (Table 1) from local ice domes. Both glaciers previously coalesced with the floating tongue of C. H. Ostenfeld, with Harder Glacier merging on the eastern side. Brikkerne Glacier sits further north, has three branches, and a small floating ice tongue which is $1.2 \mathrm{~km}$ long (Table $\mathbf{1}$ ).

Little record of these glaciers exists in the literature and there are no records of terminus change at Harder Glacier. At Brikkerne, the only frontal position data available show that the northern and central sections of the glacier advanced 11 and 8 km, respectively, between 1953 and 1978 (Higgins, 1991). Data from the 1970s showed relatively low velocities at Harder Glacier (84-122 $\mathrm{m} \mathrm{a}^{-1}$; Higgins, 1991). At Brikkerne Glacier, velocity was considered to be very slow in 1947 , increasing to $150-360 \mathrm{~m} \mathrm{a}^{-1}$ in 1963 and $500 \mathrm{~m} \mathrm{a}^{-1}$ between 1971 and 1978 (Higgins, 1991). This velocity increase coincided with periods of glacier advance (Higgins, 1991). No records of surging exist for Harder Glacier, but Brikkerne Glacier was identified as surge-type glacier on the basis of variable velocity records (Higgins, 1991; Rignot et al., 2001). Since the early studies (Higgins, 1991; Rignot et al., 2001), little attention has been paid to these glaciers, despite their potential dynamic changes such as surging at Brikkerne Glacier.

\section{Jungersen, Naravana Fjord and Henson Glaciers}

Further north from Victoria fjord lie three further outlet glaciers, Jungersen, Naravana Fjord and Henson, which collectively drain $0.7 \%$ of northern Greenland (Table 1). Both Jungersen and Henson Glaciers are $2 \mathrm{~km}$ wide (Higgins, 1991) and previously had floating sections (Rignot et al., 2001), although their length has not been reported in the literature. Naravana Fjord, located between these glaciers, is $2.5 \mathrm{~km}$ wide and has no floating section. Little is known about terminus changes at these glaciers. Grounding line data (Morlighem et al., 2015) shows they no longer have floating ice tongues (Figure 2A), suggesting their termini have retreated since previous observations (Rignot et al., 2001). Ice velocity data are limited, although Jungersen Glacier was estimated to flow at $350 \mathrm{~m} \mathrm{a}^{-1}$ in the $1970 \mathrm{~s}$, whereas Henson was barely moving (1.7 $\mathrm{m} \mathrm{a}^{-1}$; Higgins, 1991). More recent velocity estimates suggested similar velocities at Jungersen Glacier $\left(395 \mathrm{~m} \mathrm{a}^{-1}\right)$, slower flow at Naravana Fjord $\left(59 \mathrm{~m} \mathrm{a}^{-1}\right)$, and a much higher estimate for Henson Glacier $\left(286 \mathrm{~m} \mathrm{a}^{-1}\right.$ : (Rignot et al., 1997).

These glaciers have received little research attention and Rignot et al. (2001) suggested that their significance in terms of ice discharge may have been previously overstated by Koch (1928). This may explain their absence from the majority of northern Greenland research. Nevertheless, they collectively drain a similar area to Tracy Glacier $\left(\sim 3800 \mathrm{~km}^{2}\right)$, and thus represent an important component of the mass budget of the region.

\section{North NE Greenland}

At the far north-eastern margin of the GrIS lie several major outlet glaciers (Figure 1) which are Academy, Marie Sophie and Hagen Bræ Glaciers.

\section{Academy and Marie Sophie Glaciers}

Academy and Marie Sophie Glaciers collectively drain an area of $\sim 9000 \mathrm{~km}^{2}$ into Independence Fjord (Figure 5C). Academy Glacier has a much wider terminus $(8.4 \mathrm{~km})$, compared to Marie Sophie (3.9 km; Table 1), and neither glacier has a floating ice tongue (Figure 2A; Higgins, 1991; Rignot et al., 2001).

Relatively few records of terminus change exist for either glacier. At Marie Sophie, early records showed minimal retreat of 0.06-0.09 km between 1921 and 1956 and sketches by Peary (1892) suggest that Academy Glacier retreated $12 \mathrm{~km}$ between 1892 and 1956 (Davies and Krinsley, 1962). More recently, terminus changes showed substantial inter-annual variability between 2000 and 2010 (Murray et al., 2015). Academy Glacier, in particular, advanced (0.59 km) between 2008 and 2009, and subsequently retreated by a similar magnitude $(0.49 \mathrm{~km})$ in the following year (2009-2010; Murray et al., 2015). Overall, between 2000 and 2010, both Academy and Marie Sophie Glaciers underwent retreat of $0.9 \mathrm{~km}$ and $0.2 \mathrm{~km}$, respectively (Murray et al., 2015).

Early work in the 1970 s estimated velocities of $220 \mathrm{~m} \mathrm{a}^{-1}$ at Marie Sophie Glacier (Higgins, 1991). This contrasts markedly with more recent values of only $40 \mathrm{~m} \mathrm{a}^{-1}$ in 1996 (Rignot et al., 1997) and $<100 \mathrm{~m} \mathrm{a}^{-1}$ in 2006 (Joughin et al., 2010a). Initial velocity estimates (1970s) at Academy Glacier found values 
of 256 to $290 \mathrm{~m} \mathrm{a}^{-1}$ at the terminus (Higgins, 1991; Rignot et al., 1997). It then maintained a steady velocity of $270 \mathrm{~m}$ $\mathrm{a}^{-1}$ from the 1970s to the mid-1990s (Rignot et al., 2001), followed by deceleration between 1996 and 2000/01 (Rignot and Kanagaratnam, 2006). More recently, both Marie Sophie and Academy Glaciers accelerated between 2000/01 and 2005/06 (from 200 to $600 \mathrm{~m} \mathrm{a}^{-1}$ at Academy; Joughin et al., 2010a).

It has been suggested that recent increases in glacier velocity could reflect surge behavior on Academy Glacier (Rignot and Kanagaratnam, 2006). However, as the glacier has not shown multi-year advance (despite reduced retreat rates between 2004/05 and 2005/06 of 500 m; Murray et al., 2015), this is questionable. No record of surging exists for Marie Sophie Glacier.

Both glaciers are significant within northern Greenland in terms of their drainage areas, and because they have both shown variable ice velocities and retreat rates throughout the historical record. Whether variable terminus positions and flow speeds are representative of a cyclic process or surge activity remains unknown. Thus they require future consideration, particularly in terms of deciphering the impacts of external forcing vs. internal glacier dynamics.

\section{Hagen Brae}

Hagen Bræ is a large outlet glacier that is $9.4 \mathrm{~km}$ wide at the grounding line (Table 1) and drains $\sim 31,000 \mathrm{~km}^{2}$ of ice area into Hagen Fjord (Figure 5C). Previously, the terminus was pinned on two islands (Higgins, 1989, 1991). Early studies also documented a floating ice tongue $\sim 18 \mathrm{~km}$ in length between 1947 and 1978 (Davies and Krinsley, 1962; Higgins, 1989, 1991), but recent imagery (2015) suggests the floating section is only $2.1 \mathrm{~km}$ long (Table 1). Academy and Hagen Bræ Glaciers lie within two basal troughs that deepen inland, $\sim 10 \mathrm{~km}$ wide that extend $\sim 100$ $\mathrm{km}$ inland (Morlighem et al., 2014; Figure 2B).

Relatively few studies have considered terminus changes at Hagen Bræ. Early work by Higgins (1989) found the glacier terminus advanced at $0.5 \mathrm{~km} \mathrm{a}^{-1}$ during the 1970s. In 2008/09, Hagen Bræ underwent the largest retreat in a single year out of 199 outlet glaciers across Greenland during the period 2000-2010 (15 km) (Murray et al., 2015). However, the glacier also experienced $3.8 \mathrm{~km}$ of total advance between 2001 and 2007 (Murray et al., 2015).

In 1996, velocities at the terminus were $94 \mathrm{~m} \mathrm{a}^{-1}$ (Rignot et al., 2001). More recently, the glacier has accelerated substantially close to the grounding line: relatively low velocities in 2000/01 $\left(200 \mathrm{~m} \mathrm{a}^{-1}\right.$ inland and $60 \mathrm{~m} \mathrm{a}^{-1}$ at the grounding line) increased to over $600 \mathrm{~m} \mathrm{a}^{-1}$ by 2005/06 and 2007 (Joughin et al., 2010a; Moon et al., 2012). Moon et al. (2012) hypothesized that these large velocity increases may have been due to glacier surging. Several other studies have noted potential surge-type behavior at Hagen Bræ (Abdalati et al., 2001; Rignot et al., 2001). Ice velocities were higher in the 1970s (Higgins, 1991) than in 1996 (Rignot et al., 2001). In 1996, velocity decreased between the equilibrium line altitude and the glacier terminus (Rignot et al., 2001). In addition, the grounding line retreated $400 \mathrm{~m}$ (Rignot et al., 2001) between 1992 and 1996. Based on these observations, Rignot et al. (2001) suggested surging occurred in the 1970s and that the glacier was then in quiescence between 1992 and 1996. Between 2000 and 2007, large increases in velocity (Joughin et al., 2010a) coincided with $3.8 \mathrm{~km}$ of advance (Murray et al., 2015). This may suggest a second surge of Hagen Bræ. Following this potential surge event, however, the glacier retreated substantially $(15 \mathrm{~km}$; Murray et al., 2015). However, velocities remained high (2008/09) (Figure 5C). This behavior is not usually associated with the quiescent phase of a surge-cycle (Meier and Post, 1969). Thus, it could be that external forcing, or retreat from a stable position in the fjord, as opposed to internal, surge-related changes have become the primary control on terminus position at Hagen Bræ in more recent years.

Recent large retreat at Hagen Bræ and its location in a deep basal trough below sea level, might suggest the glacier is vulnerable to rapid retreat in the near-future. This glacier is significant in terms of discharge, draining 6\% of northern Greenland by area and it is surprising that this glacier has not been studied in more detail.

\section{Northeast Greenland}

The northeast region (Figure 1) consists of five outlet glaciers which are Nioghalvfjerdsfjorden (also known as 79 North), Zachariae Isstrøm, Storstrømmen, Kofoed-Hansen Bræ, and L. Bistrup Bræ. These glaciers are associated with the Northeast Greenland Ice Stream (NEGIS), which is a large, fast flowing portion of the GrIS that rests substantially below sea level (Figure 2B) and drains ice some $600 \mathrm{~km}$ into the interior of the ice sheet (Joughin et al., 2001; Reeh et al., 2001). The entire NEGIS is considered potentially unstable, having undergone substantial ice thinning since the beginning of the twenty-first century (Khan et al., 2014).

\section{Nioghalvfjerdsfjorden (79 North Glacier) and Zachariae Isstrøm}

Nioghalvfjerdsfjorden and Zachariae Isstrøm are the two main outlets of the NEGIS (Khan et al., 2014) and collectively drain around $30 \%$ of the northern GrIS by area (Rignot and Kanagaratnam, 2006; Table 1). Nioghalvfjerdsfjorden is 24 $\mathrm{km}$ wide, and has an extensive ( $\sim 69 \mathrm{~km}$ long) floating ice tongue (Figure 2A), that widens down-fjord to $30 \mathrm{~km}$ at the terminus (Thomsen et al., 1997). Zachariae Isstrøm is $27 \mathrm{~km}$ wide and terminates in an embayment typically surrounded by calved icebergs (Box and Decker, 2011). Zachariae Isstrøm previously terminated as a floating ice tongue (Figure 2A), but this dramatically disintegrated between 2000 and 2006, meaning that the glacier terminus is currently grounded (Khan et al., 2014). Both glaciers lie above deep basal troughs, which rest significantly below sea level (Mayer et al., 2000), and have a reverse bed slope (Bamber et al., 2013; Figure 2B).

Information on the frontal positions of these two glaciers has been comparatively limited due to year-round ice mélange in the fjords, resulting in an ambiguous calving region and therefore making it difficult to accurately identify the true calving front (Bevan et al., 2012; Murray et al., 2015). In 1976, the two glaciers were thought to have coalescing ice tongues (Weidick et al., 1995), which suggests they have since retreated substantially and become separated (Rignot et al., 2001). Early records from 
Nioghalvfjerdsfjorden found $20 \mathrm{~km}$ of retreat between 1950 and 1963 (Thomsen et al., 1997). Subsequently, the terminus retreated 5-7 km during 1978-2003 (Khan et al., 2014). Zachariae Isstrøm, lost $1400 \mathrm{~km}^{2}$ of its ice shelf between 2000 and 2006 (Moon and Joughin, 2008) and its grounding line has begun to rapidly retreat downslope (Mouginot et al., 2015). Both glaciers underwent similar ice loss in 2004/05, with $60 \mathrm{~km}^{2}$ of ice lost at Nioghalvfjerdsfjorden and $67 \mathrm{~km}^{2}$ at Zachariae Isstrøm (Box and Decker, 2011). Two years later, during 2006/07, both glaciers advanced, although of differing magnitudes: $8.4 \mathrm{~km}^{2}$ at Nioghalvfjerdsfjorden and $45.8 \mathrm{~km}^{2}$ at Zachariae Isstrøm (Box and Decker, 2011). Subsequently, between 2009 and 2012, sections of the Nioghalvfjerdsfjorden retreated by a further 2-3 $\mathrm{km}$ (Khan et al., 2014).

Nioghalvfjerdsfjorden and Zachariae Isstrøm were considered slow-moving in the early 1950s (Helk and Dunbar, 1953), although no specific velocity values were given. However, more recent data show that they are relatively fast-flowing reaching speeds of $>1 \mathrm{~km} \mathrm{a}^{-1}$ at their termini (Khan et al., 2014; Figure 6). No significant acceleration or deceleration was detected between 2000 and 2006 on Nioghalvfjerdsfjorden (Rignot and Kanagaratnam, 2006; Joughin et al., 2010a). However, a more recent study observed an acceleration of $100 \mathrm{~m} \mathrm{a}^{-1}$ between 2000 and 2011 (Khan et al., 2014). Zachariae Isstrøm has been accelerating since the early 2000s, increasing by up to $200 \mathrm{~m} \mathrm{a}^{-2}$, following the disintegration of part of the ice shelf in 2004/05 (Rignot and Kanagaratnam, 2006; Moon and Joughin, 2008; Joughin et al., 2010a). Acceleration then continued, although more steadily, until 2012 (Khan et al., 2014; Mouginot et al., 2015). Since 2012, ice velocities on Zachariae Isstrøm have increased by $25 \%$, accompanied by accelerated frontal retreat (Mouginot et al., 2015).

Estimates suggest that these glaciers must have experienced submarine melt rates of between 6 and $8 \mathrm{~m} \mathrm{a}^{-1}$ to explain their 1996 ice flux (Rignot et al., 1997). This is similar to submarine melt rates recorded at other northern Greenland outlet glaciers e.g., Petermann Glacier (Rignot and Steffen, 2008). The breakup of fast ice offshore of Nioghalvfjerdsfjorden in 1997 was followed by a large glacier calving event and is thus considered an important control on the rates of calving (Reeh et al., 2001).

More generally, the NEGIS is thought to be undergoing dynamic thinning as a result of climate change, losing mass at a rate of $>10 \mathrm{Gt} \mathrm{yr}^{-1}$ (Khan et al., 2014). As the NEGIS extends far into the ice sheet interior (Khan et al., 2014; Figure 2C) and sits on a reverse bed slope, these glaciers have the potential to discharge large volumes of ice. Should retreat continue at the present or increased rates (particularly at Zachariae Isstrøm; Khan et al., 2014), subsequent ice flow speed-ups could cause significant mass loss from a large inland area of the GrIS (Csatho et al., 2014). This could further destabilize this region and increase its contribution to twenty first century sea level rise.

\section{Storstrømmen, Kofoed-Hansen Bræ, and L. Bistrup Bræ}

Storstrømmen is another large outlet of the NEGIS that, along with Kofoed-Hansen Bræ, drains $\sim 120,000 \mathrm{~km}^{2}$ (Table 1). The catchment extends to the summit of the GrIS (Reeh et al., 2003;
Figure 2C). Kofoed-Hansen Bræ is the northeastern branch of Storstrømmen which discharges $\sim 25 \%$ of the Storstrømmen ice flux (Mohr et al., 1998). Storstrømmen has a two-lobed calving front, one of which drains directly into the ocean and the other of which joins with L. Bistrup Bræ to the south (Figure 6; Khan et al., 2014). L. Bistrup Bræ terminates alongside Storstrømmen and is $\sim 11 \mathrm{~km}$ wide with a catchment of $\sim 20,000 \mathrm{~km}^{2}$ (Table 1). Within this embayment, both Storstrømmen and L. Bistrup Bræ have floating ice sections (Figure 2A) that are 8.4 and $6.2 \mathrm{~km}$ long, respectively, whereas data suggests Kofoed-Hansen Bræ is grounded (Morlighem et al., 2015).

Relatively little is known about frontal position changes at these glaciers. Available data show that all three glaciers retreated between 2001 and 2005 (Seale et al. (2011). In total, this resulted in retreat of $0.3 \mathrm{~km}$ at Storstrømmen, and $0.76 \mathrm{~km}$ at both Kofoed-Hansen Bræ and L. Bistrup Bræ (Seale et al., 2011). However, during this period Storstrømmen underwent a short term advance of $0.4 \mathrm{~km}^{2}$ in 2001/02 (Box and Decker, 2011). Later, between 2005 and 2008, only Storstrømmen glacier continued to retreat, while L. Bistrup Bræ and Kofoed-Hansen Bræ both advanced by $0.29 \mathrm{~km}$ (Seale et al., 2011).

The velocity of Storstrømmen was thought to be $\sim 230 \mathrm{~m} \mathrm{a}^{-1}$ in 1996 (Rignot et al., 2001). L. Bistrup Bræ is considered slow moving, although specific values were not documented in the literature (Rignot et al., 2001), with almost zero velocity between 2000/01 and 2009/10 at the terminus (Joughin et al., 2010a). However, further inland the glacier flows at $\sim 100 \mathrm{~m} \mathrm{a}^{-1}$ in 2008/09 (Figure 6). During this same period (2000/01-2009/10) Storstrømmen Glacier decelerated by $60 \mathrm{~m} \mathrm{a}^{-2}$ (Joughin et al., 2010a).

Evidence of surging exists for all three glaciers. A surge was documented at Storstrømmen between 1978 and 1984 (Reeh et al., 1994), when the glacier advanced $\sim 12 \mathrm{~km}$. By the $1990 \mathrm{~s}$ it was considered to be quiescent (Mohr et al., 1998), and has remained so since that time (Reeh et al., 2003; Rignot and Kanagaratnam, 2006). L. Bistrup Bræ is also likely to be a surgetype glacier, based on thickening at the grounding line, although there is no direct evidence of an actual surge event. The glacier is instead hypothesized to have surged in the past and now be quiescent (Rignot et al., 2001). Both L. Bistrup Bræ and Storstrømmen have experienced very low flow speeds over the past decade, potentially indicative of quiescence (Moon et al., 2012), as well as a characteristic pattern of thickening inland, where the surge may have initiated, and thinning toward the terminus (Abdalati et al., 2001; Csatho et al., 2014). Surveys between 1995 and 1999 found thinning rates of $2 \mathrm{~m} \mathrm{a}^{-1}$ in the lower reaches of both glaciers and thickening up to $3 \mathrm{~m} \mathrm{a}^{-1}$ further inland (Thomas et al. (2009). Following this, however, thickening rates on the upper reaches of Storstrømmen began to decrease (Thomas et al., 2009).

Despite these three outlet glaciers collectively draining an area $(27 \%)$ of the GrIS, which is far greater than the wellstudied Petermann Glacier (Table 1), little previous work has focused on their dynamics. Considerable variability in terminus positions have taken place over the last two decades, particularly at Storstrømmen and L. Bistrup Bræ, which has been linked to surge activity. These glaciers are important in terms of draining a 


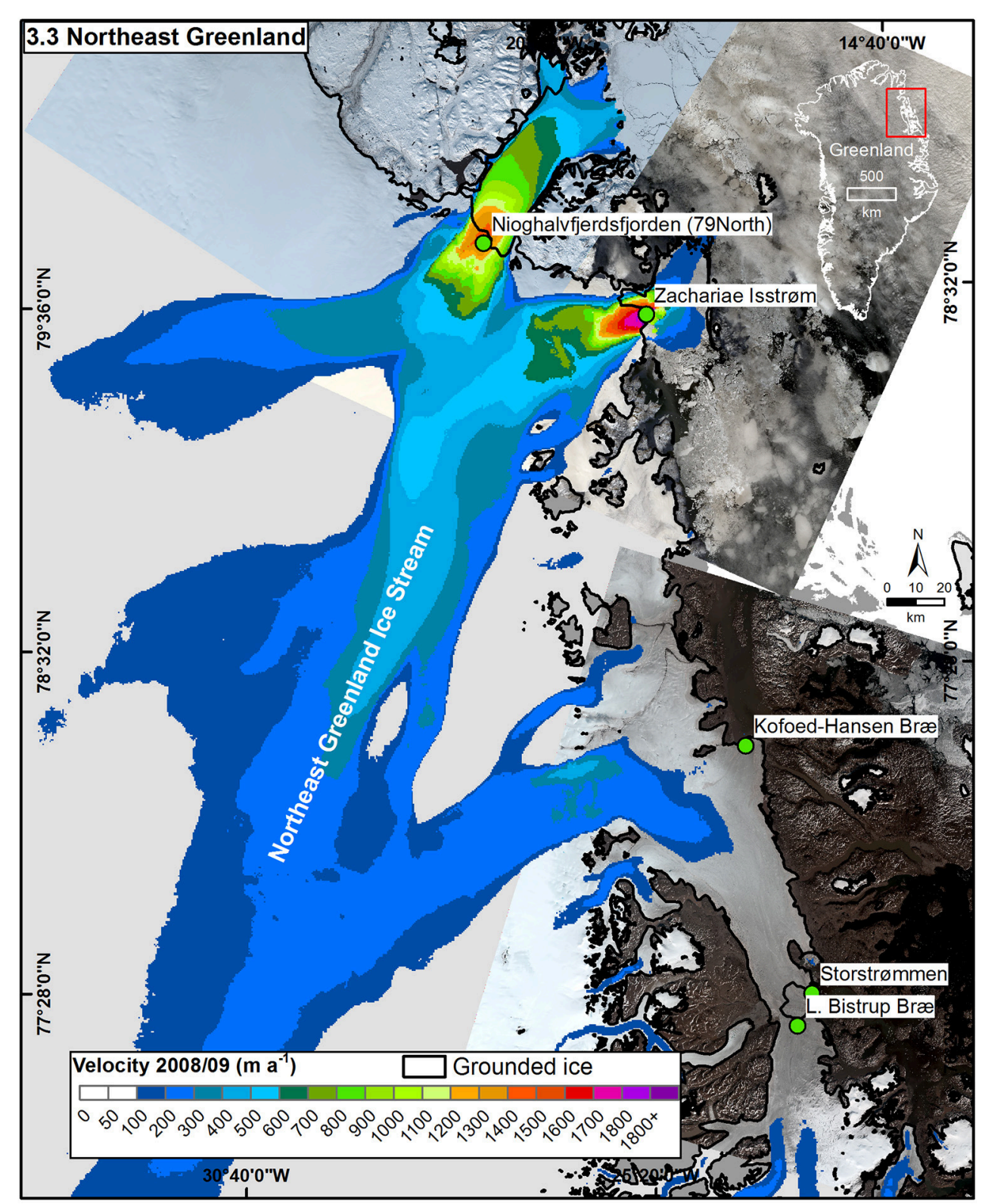

FIGURE 6 | Northeast Greenland region that includes Nioghalvfjerdsfjorden (79North), Zachariae Isstrøm, Kofoed-Hansen Bræ, Storstrømmen, and L. Bistrup Bræ. Grounded ice is shown in a black outline. Velocity is shown on each glacier in $\mathrm{m} \mathrm{a}^{-1}$. Velocity data was acquired from the 2008/2009 MEaSUREs v2 Greenland velocity (Joughin et al., 2010b). Background imagery is from Landsat 8 (late summer 2015).

large proportion of the NEGIS and it is necessary for further work to better understand their surge-nature and their implications for increased ice discharge from potentially unstable regions.

\section{Summary of Northern Greenland Outlet Glacier Changes}

Overall, substantial changes have taken place in northern Greenland, particularly during the past two decades, and there has been considerable variability between sub-regions and individual glaciers. Figure 7 summarizes the events recorded from the literature at the selected outlet glaciers in northern Greenland between 1880 and 2015. For all glaciers where records exist (17 out of 21 in Figure 7), retreat has occurred at some stage between 2000 and 2015, with the most substantial at Humboldt, Tracy, Hagen Bræ, C. H. Ostenfeld, and Petermann Glaciers. In the case of the latter three glaciers, this retreat resulted in substantial loss of their floating ice tongues. For example, Petermann Glacier lost $27 \mathrm{~km}$ of its floating ice tongue in 2010 (Falkner et al., 2011), and Hagen Bræ lost a 15 km floating 
section in 2008/09 (Murray et al., 2015). However, glacier retreat is not uniform across the region, and several glaciers underwent advance between 2000 and 2010 (e.g., L. Bistrup Bræ, KofoedHansen Bræ, and Harald Moltke Bræ). This could either reflect surge behavior (which has been hypothesized at all three of these glaciers) or a differing response to external environmental forcing, perhaps due to local topographic controls. Nevertheless, over the last 20 years, all glaciers have experienced some retreat, which would suggest a common response to external forcing.

Alongside terminus changes, our review has shown that several of the study glaciers have accelerated, particularly over the last two decades (Figure 7). However, this has not been the case at all study glaciers. This is evident in Figure 8, which uses MEaSUREs velocity data (Joughin et al., 2010b) from 2000/01

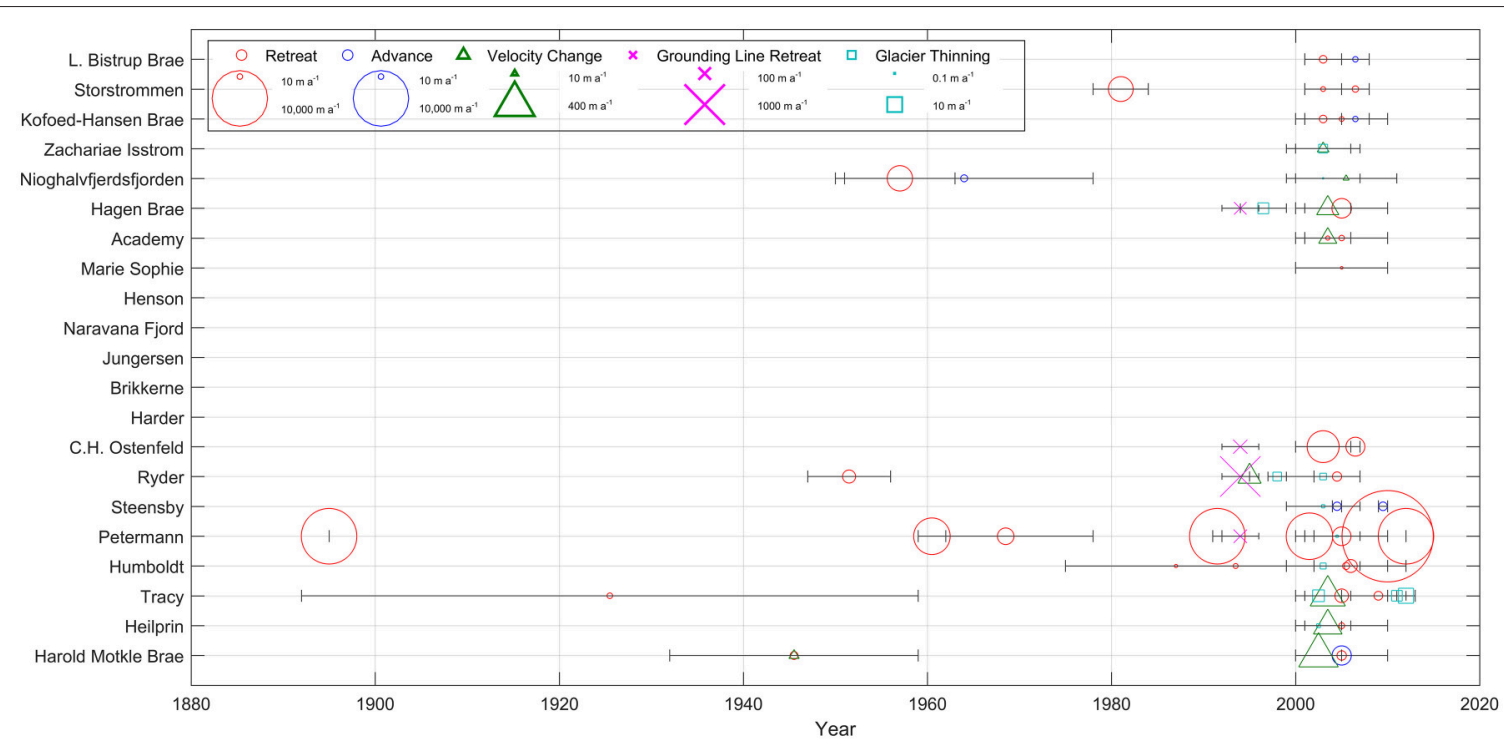

FIGURE 7 | A summary of recorded changes at northern Greenland outlet glaciers based on a review of the literature. Key events of terminus change (circles, red for retreat, blue for advance), velocity change (triangle), grounding line retreat (cross), and glacier thinning (square), that have occurred at all northern Greenland focus glaciers between 1880 and present (2015) are recorded. Data points are shown in the middle of study periods and the gray lines show the duration over which the change refers to. All data points are converted to $\mathrm{m} \mathrm{a}^{-1}$ across the study period and the size of all data points are based on $\mathrm{m} \mathrm{a}^{-1} \mathrm{magnitude}$. The legend shows the symbol sizes and their corresponding values for each category of data shown.

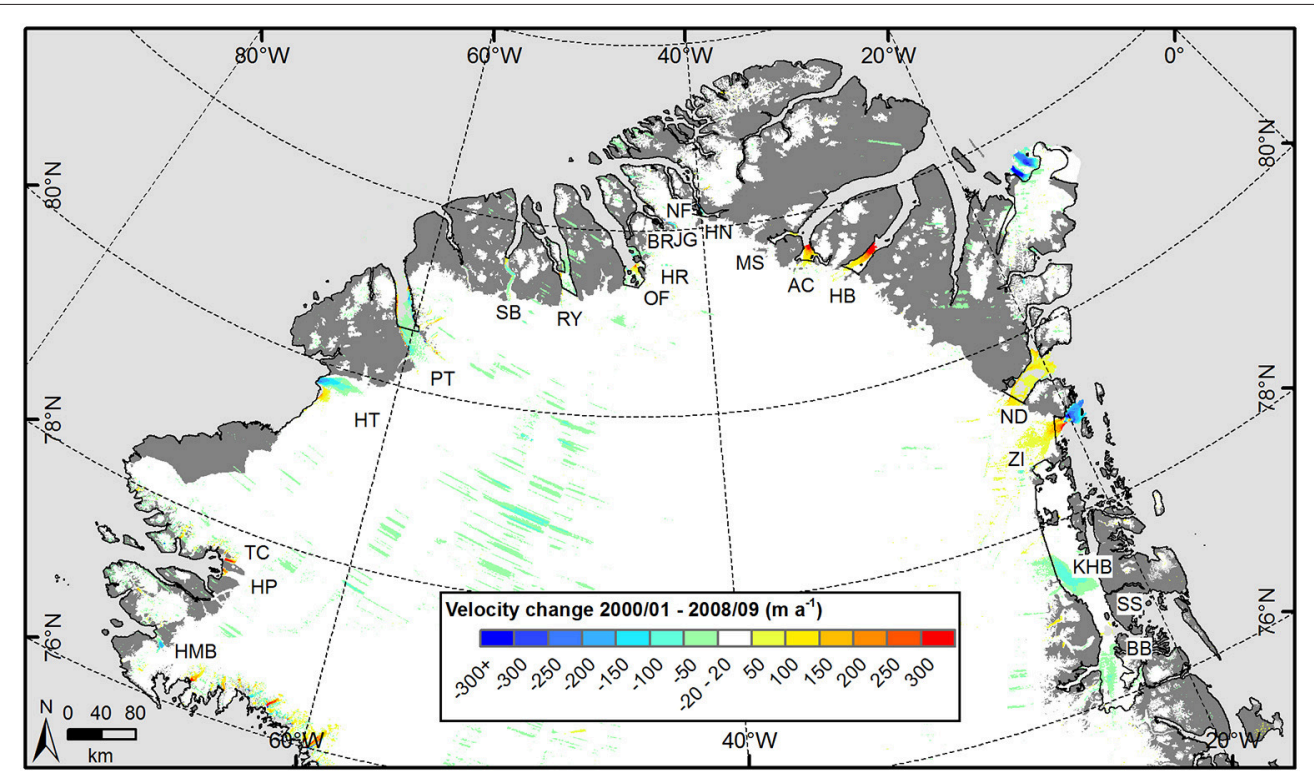

FIGURE 8 | Velocity change between winters 2000/01 and 2008/09 using MEaSUREs v2 Greenland velocity data (Joughin et al., 2010b). Orange and red colors show velocity increase, and green and blue show velocity decrease. 
and 2008/09 to show changes in velocity between these two periods across northern Greenland. These two datasets are winter velocities, between 3 September and 24 January 2000-2001 and 1 December and 28 February 2008-2009. Instead, velocity change is highly variable, with several glaciers accelerating substantially (e.g., Hagen Bræ and Academy Glacier) and others slowing (e.g., Petermann and Ryder Glaciers'). Recent velocity increases were often accompanied by glacier retreat (Figure 7), namely at Hagen Bræ, Academy, Marie Sophie, Tracy, and Heilprin Glaciers. Apart from Hagen Bræ, the retreat of large floating ice tongues (e.g., Petermann and C.H. Ostenfeld) did not appear to coincide with increased velocities. The impact of major ice tongue losses on ice velocities is therefore complex.

Figure 7 also shows that there are several glaciers in northern Greenland for which measurements of retreat, advance, and other glacier changes have not been made, particularly at the smaller glaciers such as Henson, Naravana Fjord, Jungersen, Brikkerne, and Harder. Several other glaciers have very few measurements. Further research into these large and potentially important outlet glaciers including frontal retreat and ice velocity measurements would help to improve understanding of region wide drivers on glacier retreat.

\section{DISCUSSION}

In the following sections we discuss the potential factors which may have driven recent changes in the dynamics of outlet glaciers in northern Greenland. This begins with external forcing via increasing atmospheric and oceanic temperatures, and the impact of reductions in sea ice. Following that we consider the role of glacier-specific factors as well as the potential surgedynamics of several of the study glaciers in this region. We also assess the future implications of mass loss in northern Greenland.

\section{Atmospheric and Oceanic Forcing of Glacier Change in Northern Greenland}

Recently observed changes at northern Greenland outlet glaciers may have been driven by changes in atmospheric and oceanic temperatures. Here we discuss these potential external controls on surface ice and submarine melting and their links to observed outlet glacier change across northern Greenland.

\section{Subaerial Ice Melt}

Atmospheric temperatures over the GrIS have increased significantly since the early $1990 \mathrm{~s}$, increasing by $1.7^{\circ} \mathrm{C}$ between 1991 and 2006 (Hanna et al., 2008; Box et al., 2009), which appears to have coincided with widespread glacier retreat (Moon and Joughin, 2008). Northern Greenland experienced negative mass balance between 2006 and 2012 (Khan et al., 2015), primarily due to enhanced surface melting and runoff (van den Broeke et al., 2009). Carr et al. (2013a) fit increased in air temperatures at NW and NE Greenland meteorological stations between 1990 and 2010 with a linear trend, which coincides with the dominant pattern of retreat at outlet glaciers in the region (Figure 7). In particular, the northeast region of Greenland has experienced increased discharge and melting between 2003 and 2012, which has been correlated to atmospheric warming (Khan et al., 2014). This coincides with substantial retreat of both Nioghalvfjerdsfjorden and Zachariae Isstrøm. While the majority of glaciers have shown retreat, the response is clearly nonuniform. Several of the study glaciers showed large variability in their terminus positions and sometimes advance (Storstrømmen, Kofoed-Hansen Bræ, and L. Bistrup Bræ; Box and Decker, 2011). Others showed a velocity increase of a factor of 10 (e.g., Harald Moltke Bræ and Hagen Bræ). Some of this behavior (e.g., periods of order of magnitude increased velocities accompanied by glacier advance) may be attributed to internal surging dynamics (Section Glacier Surging). Thus, whilst it is likely that increased air temperatures in northern Greenland have influenced glacier retreat over the last two decades, there has not been a coherent response.

In northern Greenland, greater surface meltwater production due to increased air temperatures has been linked to interannual retreat at Humboldt Glacier (Carr et al., 2015). Here, hydrofracture of crevasses a few kilometers inland of the glacier terminus may have caused weakening and promoted calving once the ice reached the terminus (Carr et al., 2015). At several glaciers, the presence of supraglacial lakes has also been noted (Humboldt, Ryder, Nioghalvfjerdsfjorden; Joughin et al., 1996b; Thomsen et al., 1997; Carr et al., 2015), and they are likely to be present on other outlet glaciers across northern Greenland. These lakes may enhance rates of calving through hydrofracture (e.g., Sohn et al., 1998; van der Veen, 1998; Carr et al., 2015), and the role of supraglacial lakes in northern Greenland, particularly across the NEGIS, could become increasingly important in the future (Ignéczi et al., 2016).

In other areas of the ice sheet it was initially thought that increased meltwater inputs led to seasonal-scale velocity increases (Zwally et al., 2002; Pimentel and Flowers, 2010). However, more recent work has linked increased meltwater production to a net annual slowdown in velocity, due to the drainage systems capacity to adjust and more efficiently drain adjacent high pressure areas via larger subglacial channels (Sole et al., 2013; Tedstone et al., 2015). Numerical modeling results suggest that the influence of meltwater inputs on seasonal velocity variations at Peterman Glacier is substantial (Nick et al., 2012), but little is known about this effect elsewhere in northern Greenland. To date, the potential impact of supraglacial lakes on northern Greenland outlet glaciers and their floating ice tongues has not been assessed. Based on observations from Antarctic ice shelves (Banwell et al., 2013), supraglacial lake drainages may play a role in calving events from large floating ice tongues by fracturing and weakening the ice. Further work to measure the occurrence, volume, and timing of supraglacial lake drainages is required due to the abundance of floating ice tongues in northern Greenland.

\section{Submarine Melt}

Alongside the role of surface meltwater induced changes discussed above, rates of submarine melt, primarily along the base of floating ice tongues, is likely to be an important control on glacier dynamics in northern Greenland. Submarine melt is likely to depend on both ocean temperature trends 
and topographic controls, whereby fjord configuration and depth control the access of sub-surface waters to glacier fronts. Submarine melt may be further enhanced by submarine meltwater plumes discharged at the grounding line (Motyka et al., 2003; Jenkins, 2011), where the more buoyant freshwater discharge promotes the circulation of deep warm water toward the grounding line (Motyka et al., 2003, 2011). Subglacial discharge is considered another primary control on submarine melt rates (Jenkins, 2011; Xu et al., 2012; Motyka et al., 2013; Sciascia et al., 2013), which could be strongly influenced by the amount of meltwater produced at the glacier surface and thus ultimately forced by atmospheric temperature changes.

Across the study region, ocean temperatures have been identified as a key control on outlet glacier behavior and ice tongue disintegration. In contrast to other areas of the GrIS, ice loss is thought be dominated by submarine melting on large floating ice tongues (Reeh et al., 1999; Rignot et al., 2001). At Nioghalvfjerdsfjorden and Zachariae Isstrøm, recent retreat rates may be due to high rates of submarine melt ( $\sim 6$ to $8 \mathrm{~m} \mathrm{a}^{-1}$; Rignot et al., 1997). Similarly, at Petermann and Tracy Glaciers, the intrusion of warm ocean water beneath floating ice tongues could have contributed to high rates of submarine melting, reaching up to $25 \mathrm{~m} \mathrm{a}^{-1}$ beneath Petermann Glacier (Rignot and Steffen, 2008), and subsequent ice tongue disintegration (Johnson et al., 2011; Johannessen et al., 2013; Porter et al., 2014). At Petermann Glacier, it was hypothesized that warmer ocean waters may have been a precursor to the large calving event in 2010 (Johannessen et al., 2013), where basal channels beneath the floating ice tongue underwent the greatest thinning (Münchow et al., 2014). Thus, Petermann Glacier's floating ice tongue is considered vulnerable to the temperature of relatively warm subsurface water entering the fjord (Johnson et al., 2011). We thus suggest the interaction between floating ice tongues and the ocean could have important implications for submarine-melt induced ice tongue collapse elsewhere in northern Greenland. However, limited in situ measurements of submarine melt rates, ocean temperatures (Thomsen et al., 1997), fjord circulation, and meltwater plumes means the extent of this process across northern Greenland remains unknown.

Forecasts suggest that ocean temperatures and submarine melt rates are likely to increase with future climate warming (e.g., Collins et al., 2013). As submarine melt rates of between 6 and $25 \mathrm{~m} \mathrm{a}^{-1}$ dominates mass loss at several northern Greenland outlet glaciers (e.g., Petermann, Nioghalvfjerdsfjorden, and Zachariae Isstrøm; Rignot et al., 2001), and has the potential to greatly influence glacier stability, there is need for improved fjord temperature data to better estimate submarine melt rates and the role of subglacial meltwater plumes (Nick et al., 2012). Systematic measurements of surface mass balance vs. submarine melting and calving are also required to better understand the importance of these processes of mass loss for many glaciers in northern Greenland. Northern Greenland glaciers are likely to be particularly vulnerable to ocean warming, due to the presence of extensive floating ice tongues, with large surface areas susceptible to submarine-melt induced collapse.

\section{Sea Ice Influence}

Sea ice has previously been identified as an important control on glacier stability and calving rates, both in Greenland (Joughin et al., 2008b; Amundson et al., 2010) and elsewhere (e.g., Miles et al., 2016). Northern Greenland glaciers may be particularly susceptible to this control, as they have long floating ice tongues, which are likely to be more sensitive to changes in buttressing provided by sea ice than grounded glaciers (Reeh et al., 2001). Indeed, this was first hypothesized in northern Greenland by Higgins (1989), who suggested that icebergs discharged from outlet glaciers in this region are held in place by semi-permanent sea ice for extended periods of time. Northern Greenland is characterized by multi-year sea ice, which undergoes periodic disintegration events. These are thought to allow the release of icebergs and to reduce back stress, thus promoting calving events and glacier retreat (Higgins, 1991; Reeh et al., 2001). Subsequent studies at Humboldt (Carr et al., 2015) and Petermann (Johannessen et al., 2013) have partly supported this theory, although the relationship appears to be more complex. At Petermann, the impact of sea ice buttressing appears to be less important than surface melt on seasonal velocity increases (Nick et al., 2012), whilst at Humboldt, icebergs were able to move away from the terminus, despite the formation of winter sea ice (Carr et al., 2015).

The outlets of the NEGIS are thought to be particularly susceptible to the effects of sea ice buttressing (Khan et al., 2014). At Nioghalvfjerdsfjorden, evidence suggests that sea ice holds icebergs in place at the calving front (Helk and Dunbar, 1953; Reeh et al., 2001), and that sea ice disintegration led to a large calving event in August 1997 (Reeh et al., 2001). Ten kilometers of frontal retreat occurred at Zachariae Isstrøm during 2002-2003, which led to the complete loss of its floating ice tongue (Mouginot et al., 2015). Khan et al. (2014) linked this to reduced sea ice concentration, due to high atmospheric temperatures, however, others have suggested it was primarily due to warmer subsurface temperatures (Mouginot et al., 2015). With Arctic sea ice predicted to decrease in the near-future (e.g., Collins et al., 2013), there is clear potential for reduced sea ice buttressing on glacier termini to allow for faster, enhanced ice discharge from the northern regions of the ice sheet. However, uncertainty remains as to the importance of sea ice buttressing on all outlet glaciers in northern Greenland. There is therefore a need for more detailed study of the impact of these processes on glacier retreat and inland ice velocities.

\section{Glacier-Specific Factors}

Across the GrIS, glacier-specific factors (basal topography and fjord geometry) have been identified as the cause of differing glacier responses to external climatic forcing (Howat and Eddy, 2011; Enderlin et al., 2013), and research suggests that this is also the case in northern Greenland (e.g., Porter et al., 2014; Carr et al., 2015). This section presents evidence for the effect of glacier geometry, the presence of floating ice tongues, and basal topography, on outlet glacier dynamics in northern Greenland. 


\section{Fjord Width}

Fjord width has been shown to have a strong influence on glacier dynamics (e.g., Jamieson et al., 2012; Enderlin et al., 2013; Carr et al., 2015). Fjord width variations can influence the stability of marine-terminating outlet glacier front positions by either promoting equilibrium or advance in a narrowing fjord, or rapid retreat in a widening fjord (e.g., Benn et al., 2007; Carr et al., 2014). At Petermann Glacier, the narrow fjord is thought to hinder the movement of icebergs away from the glacier front, which may facilitate ice mélange formation, which, also referred to as sikussak, is defined as a mixture of calved icebergs and sea ice. This mélange may "choke" the fjord with icebergs, which could exert resistive back-stress on the glacier tongue (Johnson et al., 2011). This ice mélange has been identified as a key control on iceberg calving rates elsewhere in Greenland (Amundson et al., 2010; Cassotto et al., 2015). Narrow fjords may also result in more ice contact with the fjord walls and, consequently, greater lateral drag exerted on the glacier sides (Raymond, 1996). These processes may apply to other glaciers in the region, several of which also terminate in narrow fjords (e.g., Ryder, Steensby and Hagen Bræ), and there is large variability in fjord geometries across northern Greenland, ranging from the wide Humboldt Glacier to the narrow sinuous fjord at Steensby Glacier. Thus, contrasting fjord widths between glaciers in northern Greenland could contribute to their varying response to external drivers.

\section{Floating Ice Tongues}

Changes in the floating ice tongues in front of several outlet glaciers in northern Greenland are another glacier-specific factor which could have influenced past glacier dynamics in northern Greenland. Table 1 highlights glaciers in the region which still have floating ice tongues and those where they have been lost. Changes in buttressing forces provided by floating ice tongues can influence glacier velocities (Howat et al., 2007; Nick et al., 2009, 2012). Floating ice shelf collapse led to increased glacier velocities at the Larsen B ice shelf in Antarctica (Scambos, 2004) and there is potential for this process to occur at floating ice tongue terminating outlet glaciers in northern Greenland. However, little increase in velocities at Petermann Glacier (Nick et al., 2012; Johannessen et al., 2013) and C. H. Ostenfeld Glacier (Joughin et al., 2010a) were found following ice tongue collapse, suggesting this may not be the case. This is of key consideration in the future, as further ice tongue retreat at northern Greenland outlet glaciers could substantially increase ice velocities, although modulated by ice shelf and fjord specific characteristics.

\section{Basal Topography}

In contrast to most of the rest of the ice sheet (Bamber et al., 2013; Morlighem et al., 2014), a large proportion of northern Greenland rests below sea level and is characterized by deep fjords beneath outlet glaciers (Figure 2B). The regions with the greatest areas below sea level are at Nioghalvfjerdsfjorden and Zachariae Isstrøm, Humboldt, and Petermann Glaciers (Figure 2B). At Nioghalvfjerdsfjorden and Zachariae, the basal trough extends $\sim 130 \mathrm{~km}$ to the interior of the ice sheet and reaches up to $550 \mathrm{~m}$ below sea level (Figure 2B). Evidence from Humboldt Glacier also shows that basal topography can have a major impact on glacier retreat and ice velocities (Carr et al., 2015). Here, retreat and ice velocities are an order of magnitude greater in the northern sector, which is underlain by a deep basal trough (up to $475 \mathrm{~m}$ deep) and an inland-sloping bed. The southern section, is comparatively shallow ( $\sim 220 \mathrm{~m}$ deep) and slopes upwards inland (Rignot et al., 2001; Carr et al., 2015). Petermann Glacier also has a deep channel that extends to the interior of the ice sheet (Bamber et al., 2013; Morlighem et al., 2014) which could have a substantial impact on ice dynamics.

At some of the smaller glaciers in northern Greenland, basal topography has also been identified as a potentially important control on dynamics. In particular, contrasting basal topography may have been responsible for the differing rates of retreat at Heilprin and Tracy Glaciers, where a deeper bed beneath Tracy Glacier allows a greater ice area to be subject to warmer ocean waters and associated increased submarine melt rates (Porter et al., 2014). Similarly, at Hagen Bræ and Academy Glaciers, deep basal troughs could be susceptible to ocean warming and linked to glacier instability (Morlighem et al., 2014). However, an alternative explanation for increased flow velocities at Hagen Bræ, may be the loss resistance as the glacier retreated from being in contact with an island pinning point (Joughin et al., 2010a). Basal topography is also important at Ryder Glacier, through its impact on water storage and short-term velocity variations (Joughin et al., 1996b; Abdalati et al., 2001). Thus, basal topography is likely to be an important control on observed glacier retreat and could have important implications for future instability in northern Greenland.

Of further consideration is the nature of the bed, which can have a key influence on ice-sheet dynamics. In particular, beneath the NEGIS, a weak, deforming bed has been suggested responsible for its streaming flow (Joughin et al., 2001; Layberry and Bamber, 2001), similar to that observed at ice streams in Antarctica (e.g., Bindschadler et al., 2001). More recent work supports this hypothesis that water-saturated till contributes to the flow speed on the NEGIS (Christianson et al., 2014). However, this, alongside the effect of subglacial geology, remain understudied in Greenland in contrast to Antarctica (Walter et al., 2014), and deserves further research.

Differences in bed topography, fjord geometry, and the presence of floating ice tongues at outlet glaciers across northern Greenland are likely to partly explain the varying responses in glacier dynamics observed. However, little examination of glacier specific factors on outlet glacier retreat have been conducted in northern Greenland and we therefore identify this as a key area for future research.

\section{Glacier Surging}

Some changes in northern Greenland glacier dynamics may not be driven by climatic forcing, and instead relate to surge behavior. Whilst the majority of northern Greenland glaciers have retreated over the last two decades, a number have undergone periods of advance (Figure 7).

Several glaciers within the study region have been previously identified as surge-type and, based on the evidence presented in this review, we have classified the study glaciers according to their potential surge likelihood (Figure 1). (i) Glaciers where 
surge-type cycles have been observed are defined as "Likely;" (ii) Glaciers which have shown surge characteristics but either have not been referred to as surge-type or have not undergone a large surge event (e.g., Ryder) are defined as "Possibly;" and (iii) glaciers at which no evidence has been recorded in the literature about surging are classed as "No Evidence."

Eight of the twenty-one glaciers reviewed have been referred to as surge-type within the literature (Table 1; Figure 1), although the evidence for surging varies from glacier to glacier. Harald Moltke Bræ, Brikkerne, Storstrømmen, and L. Bistrup Bræ have all undergone periods of advance, alongside an order of magnitude increase in glacier velocity (Mock, 1966; Higgins, 1991; Reeh et al., 1994; Seale et al., 2011), and we therefore consider it likely these are true surge-type glaciers, which fit the above definition (Figure 1). A potential surge event in northern Greenland that received notable research attention was a "mini-surge" at Ryder Glacier in 1995, during which velocity increased at least three-fold over a 7-week period (Joughin et al., 1996b). However, as no further or larger surge events have been recorded, we deem it "Possibly" surge-type. We assign the same classification to Hagen Bræ (Figure 1). Here, past acceleration has been attributed to surge behavior, but it is unclear whether surging persists today and recent velocity increases may instead be attributed to reduced resistive stresses at the terminus, due to retreat from basal pinning points (Joughin et al., 2010a). The neighboring Academy Glacier also experienced an order of magnitude increase in ice velocity between 2000 and 2006 (Joughin et al., 2010a), which is suggestive of surge behavior (Rignot and Kanagaratnam, 2006). However, the glacier continued to retreat during this period, albeit at a reduced rate (Murray et al., 2015).

As previously stated, glacier surges may either by thermally or hydrologically controlled (Murray et al., 2003). At Ryder Glacier, it is likely the mini-surge was hydrologically induced due to its underlying topography. Two transverse subglacial ridges beneath the glacier were suggested to have allowed water ponding upstream and, once it reached a critical pressure threshold, could have initiated the surge (Joughin et al., 1996b, 1999; Rignot et al., 2001). However, the drainage of supraglacial lakes and waterfilled crevasses may also have been at least partly responsible for the surge event (Joughin et al., 1996b). Given recent advances in our understanding of GrIS dynamics (Das et al., 2008; Sole et al., 2013; Bougamont et al., 2014), we hypothesize that it is unlikely the "mini-surge" event at Ryder Glacier (Joughin et al., 1996b) satisfies a strict definition (Meier and Post, 1969; Sharp, 1988) of surging. Instead it may reflect a seasonal speed up event, similar to which has been seen on the west coast of Greenland (Palmer et al., 2011; Doyle et al., 2015). Such acceleration events appear to be followed by an extra slowdown (Meier et al., 1994), which offsets the annual average (Sole et al., 2013). However, more recent work recorded substantial glacial advance during several years between 2000 and 2010 (Box and Decker, 2011; Murray et al., 2015), which may suggest surging is continuing at Ryder Glacier. Thus it remains unclear whether these advances were internally or externally controlled and whether Ryder Glacier is of true surge-type requires further study.
Generally, surge type glaciers have not been systematically identified across Greenland, apart from in eastern Greenland (Jiskoot et al., 2003; Pritchard et al., 2005). As such, large uncertainties remain as to the nature of surge-type glaciers in northern Greenland, and the possible surge mechanisms have been little-studied. Thus, with several glaciers in northern Greenland having been referred to as "surge type" there is an important need for further research to provide a comprehensive account of surge behavior in northern Greenland and to separate this behavior from changes driven by external forcing.

\section{FUTURE CHANGES}

An important consideration in northern Greenland is the region's sensitivity to future climate change. During the period 2081-2100, average Arctic air temperatures are expected to be $4.2^{\circ} \mathrm{C}$ warmer than present under Representative Concentration Pathway (RCP) 4.5 and $8.3^{\circ} \mathrm{C}$ warmer under RCP8.5 (Collins et al., 2013).

As northern Greenland experiences the lowest accumulation rates across the ice sheet (Goelzer et al., 2013) and warming in these high latitudes is expected to be greatest (Gregory and Huybrechts, 2006), it is likely the northern regions of the ice sheet could be more sensitive to future climate change. However, this will also be dependent on how much additional precipitation may be delivered by a warmer atmosphere. Of particular concern to northern Greenland is that simulations of surface melt show the largest amplification in northern Greenland (Fettweis et al., 2012), due to reduced sea ice cover as a result of increased air temperatures (Mernild et al., 2010; Franco et al., 2011). Recent work has also shown an exceptional atmospheric ridge led to greater runoff, low albedo, and higher surface temperatures in the northern regions of the GrIS during 2015 (Tedesco et al., 2016). Goelzer et al. (2013) also showed large negative surface mass balance anomalies to occur around the north coast of Greenland between 2091 and 2100 obtained from a positive degree day model relative to 1989-2008 reference period. Recent studies in northern Greenland have also suggested that increased temperatures and subsequent enhanced surface melt have the potential to weaken floating ice tongues (Johannessen et al., 2013). While several of the glaciers in northern Greenland have shown acceleration and retreat (Figure 7), this is not ubiquitous and ambiguity exists as to the velocity response of northern Greenland outlet glaciers to ice tongue loss in the future.

At Petermann Glacier, future projections driven by atmospheric warming (A1B scenario) show the glacier to primarily lose mass by surface melt between 2000 and 2100, which is in contrast to Helheim and Kangerdlugssuaq glaciers, which instead lose mass via dynamic mechanisms (Nick et al., 2013). Further projections between 2100 and 2200, however, showed dynamic mass losses through increased rates of submarine melt to become far greater at Petermann (Nick et al., 2013). Few other studies have considered outlet glacier response to future climate change at specific outlets in northern Greenland. Thus, substantial uncertainty remains as to the regions sensitivity to future atmospheric and oceanic temperature changes. We therefore suggest further consideration 
of terminus changes, particularly the loss of floating ice tongues across the entirety of northern Greenland, their effect on ice dynamics, and their relationship to atmospheric/oceanic temperatures, is necessary to better understand and predict future changes under a warmer climate.

\section{CONCLUSIONS}

Northern Greenland is an important region of the GrIS because it consists of large fast-flowing marine-terminating outlet glaciers, draining a significant area of the ice sheet (collectively, around $40 \%$ of the ice sheet area is drained by 21 glaciers), of which a large proportion sits below sea level. This paper reviewed previously published work focusing on 21 major outlet glaciers in northern Greenland to provide a synthesis of changes in their dynamics between the late nineteenth century and 2015, and potential links to changes in the ocean-climate system. A clear conclusion from this analysis is that all glaciers have retreated over the last century and that this retreat has accelerated in the last two decades. Indeed, several glaciers have shown kilometer-scale retreat $(>10 \mathrm{~km})$ over the last two decades, in particular at Petermann, Hagen Bræ, Tracy, Zachariae Isstrøm, and C. H. Ostenfeld Glaciers. The flow velocity of a number of outlets has also accelerated during this period (e.g., Academy and Hagen Bræ). Despite an overall pattern of retreat, however, we also note variability in glacier response, which likely results from differing sensitivity to various forcings (e.g., air vs. ocean temperatures) and/or local factors, such as fjord geometry or the presence of floating ice tongues. Indeed, the impact of ice tongue retreat on glacier velocity remains uncertain because some glaciers experienced enhanced velocities (e.g., Hagen Bræ), but others showed only a limited response (Petermann and C. H. Ostenfeld). There is also some confusion surrounding the possibility of surge-type glaciers in this region, which add further complexity when attempting to elucidate the precise drivers of glacier change.

Given the above, large uncertainty surrounding glacier responses to external factors in northern Greenland remain. While several studies have focused on the major calving event at Petermann Glacier in 2010, it remains unclear whether this was exceptional or part of a long-term cyclical trend. Studies of a similar nature, comprising detailed measurements of frontal

\section{REFERENCES}

Abdalati, W., Krabill, W., Frederick, E., Manizade, S., Martin, C., Sonntag, J., et al. (2001). Outlet glacier and margin elevation changes: near-coastal thinning of the Greenland Ice Sheet. J. Geophys. Res. 106, 33729-33741. doi: $10.1029 / 2001$ JD900192

Ahnert, F. (1963). The terminal disintegration of Steensby Gletscher, north Greenland. J. Glaciol. 4, 537-545.

Amundson, J. M., Fahnestock, M., Truffer, M., Brown, J., Lüthi, M. P., and Motyka, R. J. (2010). Ice mélange dynamics and implications for terminus stability, Jakobshavn Isbræ, Greenland. J. Geophys. Res. 115:F01005. doi: 10.1029/2009JF001405

Bamber, J. L., Griggs, J. A., Hurkmans, R. T. W. L., Dowdeswell, J. A., Gogineni, S. P., Howat, I., et al. (2013). A new bed elevation dataset for Greenland. Cryosphere 7, 499-510. doi: 10.5194/tc-7-499-2013 retreat and ice velocity are needed for surrounding outlet glaciers in northern Greenland to improve our understanding of the factors that are forcing recent outlet glacier retreat in the region. Future work could usefully focus on improving high resolution data, in particular fjord bathymetry and ocean temperatures, alongside assessing the role of glacier specific factors (e.g., through numerical modeling), to better understand the links between climatic-oceanic forcing and local topographic factors. Further work is also required to systematically classify surgetype glaciers in the region, and help distinguish externally-driven retreat from internally-driven surge cycles that may not be related to changes in the ocean-climate system.

\section{AUTHOR CONTRIBTUIONS}

$\mathrm{EH}$ designed and led the writing of the manuscript. RC and CS contributed ideas and provided editorial input on both the manuscript and the figures.

\section{FUNDING}

This project was funded by a Doctoral Studentship awarded to EH for 3.5 years by the Natural Environment Research Council and through the IAPETUS Doctoral Training Partnership (grant number NE/L002590/1).

\section{ACKNOWLEDGMENTS}

$\mathrm{EH}$ was funded by the IAPETUS Natural Environment Research Council Doctoral Training Partnership (grant number

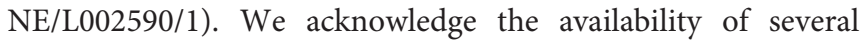
free datasets, which we have used to produce the Figures in this review. Version 2 of the IceBridge Bed Machine dataset was acquired from the National Snow and Ice Data Center (NSIDC) produced by Morlighem et al. (2015). We also acknowledge the use of several years of MEaSUREs Greenland Ice Velocity dataset also acquired from the NSIDC and produced by Joughin et al. (2010b). Several Landsat 8 scenes were sourced from the United States Geological Survey's Earth Explorer platform. We would like to thank two reviewers and the Editor for their comments on an earlier version of the manuscript.

Banwell, A. F., MacAyeal, D. R., and Sergienko, O. V. (2013). Breakup of the Larsen B Ice Shelf triggered by chain reaction drainage of supraglacial lakes. Geophys. Res. Lett. 40, 5872-5876. doi: 10.1002/2013GL 057694

Benn, D. I., Warren, C. R., and Mottram, R. H. (2007). Calving processes and the dynamics of calving glaciers. Earth Sci. Rev. 82, 143-179. doi: 10.1016/j.earscirev.2007.02.002

Bevan, S. L., Luckman, A. J., and Murray, T. (2012). Glacier dynamics over the last quarter of a century at Helheim, Kangerdlugssuaq and 14 other major Greenland outlet glaciers. Cryosphere 6, 923-937. doi: 10.5194/tc-6923-2012

Bindschadler, R., Bamber, J., and Anandakrishnan, S. (2001). "Onset of streaming flow in the siple coast region, West Antarctica," in The West Antarctic Ice Sheet: Behavior and Environment, eds R. B. Alley and R. A. Bindschadler (Washington, DC: American Geophysical Union). doi: 10.1029/AR077p0123 
Bougamont, M., Christoffersen, P., Fitzpatrick, A. A., Doyle, S. H., and Carter, S. P. (2014). Sensitive response of the Greenland Ice Sheet to surface melt drainage over a soft bed. Nat. Commun. 5:5052. doi: 10.1038/ncomms6052

Box, J. E., and Decker, D. T. (2011). Greenland marine-terminating glacier area changes: 2000-2010. Ann. Glaciol. 52, 91-98. doi: 10.3189/1727564 11799096312

Box, J. E., Yang, L., Bromwich, D. H., and Bai, L.-S. (2009). Greenland Ice Sheet surface air temperature variability: 1840-2007. J. Clim. 22, 4029-4049. doi: 10.1175/2009JCLI2816.1

Carr, J. R., Stokes, C. R., and Vieli, A. (2013a). Recent progress in understanding marine-terminating Arctic outlet glacier response to climatic and oceanic forcing: Twenty years of rapid change. Prog. Phys. Geogr. 37, 436-467. doi: $10.1177 / 0309133313483163$

Carr, J. R., Stokes, C., and Vieli, A. (2014). Recent retreat of major outlet glaciers on Novaya Zemlya, Russian Arctic, influenced by fjord geometry and sea-ice conditions. J. Glaciol. 60, 155-170. doi: 10.3189/2014JoG13J122

Carr, J. R., Vieli, A., and Stokes, C. R. (2013b). Influence of sea ice decline, atmospheric warming, and glacier width on marine-terminating outlet glacier behavior in northwest Greenland at seasonal to interannual timescales. J. Geophys. Res. Earth Surf. 118, 1210-1226. doi: 10.1002/jgrf.20088

Carr, J. R., Vieli, A., Stokes, C. R., Jamieson, S. S. R., Palmer, S. J., Christoffersen, P., et al. (2015). Basal topographic controls on rapid retreat of Humboldt Glacier, northern Greenland. J. Glaciol. 61, 137-150. doi: 10.3189/2015JoG14J128

Cassotto, R., Fahnestock, M., Amundson, J. M., Truffer, M., and Joughin, I. (2015). Seasonal and interannual variations in ice melange and its impact on terminus stability, Jakobshavn Isbr \& aelig, Greenland. J. Glaciol. 61, 76-88. doi: 10.3189/2015JoG13J235

Christianson, K., Peters, L. E., Alley, R. B., Anandakrishnan, S., Jacobel, R. W., Riverman, K. L., et al. (2014). Dilatant till facilitates ice-stream flow in northeast Greenland. Earth Planet. Sci. Lett. 401, 57-69. doi: 10.1016/j.epsl.2014.05.060

Collins, M., Knutti, R., Arblaster, J., Dufresne, J.-L., Fichefet, T., Friedlingstein, P., et al. (2013). "Long-term climate change: projections, commitments and irreversibility," in Climate Change 2013: The Physical Science Basis. Contribution of Working Group I to the Fifth Assessment Report of the Intergovernmental Panel on Climate Change, eds T. F. Stocker, D. Qin, G. K. Plattner, M. Tignor, S. K. Allen, J. Boschung et al. (Cambridge; New York, NY: Cambridge University Press), 1029-1136.

Cook, S., Rutt, I. C., Murray, T., Luckman, A., Zwinger, T., Selmes, N., et al. (2014). Modelling environmental influences on calving at Helheim Glacier in eastern Greenland. Cryosphere 8, 827-841. doi: 10.5194/tc-8-827-2014

Csatho, B. M., Schenk, A. F., van der Veen, C. J., Babonis, G., Duncan, K., Rezvanbehbahani, S., et al. (2014). Laser altimetry reveals complex pattern of Greenland Ice Sheet dynamics. Proc. Natl. Acad. Sci. U.S.A. 111, 18478-18483. doi: $10.1073 /$ pnas. 1411680112

Das, S. B., Joughin, I., Behn, M. D., Howat, I. M., King, M. A., Lizarralde, D., et al. (2008). Fracture propagation to the base of the Greenland Ice Sheet during supraglacial lake drainage. Science 320, 778-781. doi: 10.1126/science.1153360

Davies, W. E., and Krinsley, D. B. (1962). The recent regimen of the ice cap margin in northern Greenland. Int. Assoc. Sci. Hydrol. Publ. 58, 119-130.

Dawes, P. R., and van As, D. (2010). An advancing glacier in a recessive ice regime: Berlingske Bræ, North-West Greenland. Geol. Surv. Den. Greenl. Bull. $20,79-82$.

Doyle, S. H., Hubbard, A., Van De Wal, R. S., van As, D., Scharrer, K., Meierbachtol, T. W., et al. (2015). Amplified melt and flow of the Greenland Ice Sheet driven by late-summer cyclonic rainfall. Nat. Geosci. 8, 647-653. doi: $10.1038 /$ ngeo2482

Dunbar, M. (1978). Petermann Gletscher: possible source of a tabular iceberg off the coast of Newfoundland. J. Glaciol. 20, 595-597.

Enderlin, E. M., Howat, I. M., and Vieli, A. (2013). High sensitivity of tidewater outlet glacier dynamics to shape. Cryosphere 7, 1007-1015. doi: 10.5194/tc-7-1007-2013

Falkner, K. K., Melling, H., Münchow, A. M., Box, J. E., Wohlleben, T., Johnson, H. L., et al. (2011). Context for the recent massive petermann glacier calving event. EOS Trans. Am. Geophys. Union 92, 117-118. doi: 10.1029/2011EO140001

Fettweis, X., Franco, B., Tedesco, M., van Angelen, J. H., Lenaerts, J. T. M., van den Broeke, M. R., et al. (2012). Estimating Greenland Ice Sheet surface mass balance contribution to future sea level rise using the regional atmospheric climate model MAR. Cryosphere Discuss. 6, 3101-3147. doi: 10.5194/tcd-6-3101-2012

Fowler, A. C., Murray, T., and Ng, F. S. L. (2001). Thermally controlled glacier surging. J. Glaciol. 47, 527-538. doi: 10.3189/172756501781831792

Franco, B., Fettweis, X., Erpicum, M., and Nicolay, S. (2011). Present and future climates of the Greenland Ice Sheet according to the IPCC AR4 models. Clim. Dyn. 36, 1897-1918. doi: 10.1007/s00382-010-0779-1

Fürst, J. J., Goelzer, H., and Huybrechts, P. (2015). Ice-dynamic projections of the Greenland Ice Sheet in response to atmospheric and oceanic warming. Cryosphere 9, 1039-1062. doi: 10.5194/tc-9-1039-2015

Goelzer, H., Huybrechts, P., Fürst, J. J., Nick, F. M., Andersen, M. L., Edwards, T. L., et al. (2013). Sensitivity of Greenland Ice Sheet projections to model formulations. J. Glaciol. 59, 733-749. doi: 10.3189/2013JoG12J182

Gregory, J. M., and Huybrechts, P. (2006). Ice-sheet contributions to future sea-level change. Philos. Trans. A Math. Phys. Eng. Sci. 364, 1709-1731. doi: 10.1098/rsta.2006.1796

Hanna, E., Huybrechts, P., Steffen, K., Cappelen, J., Huff, R., Shuman, C., et al. (2008). Increased Runoff from Melt from the Greenland Ice Sheet: a response to global warming. J. Clim. 21, 331-341. doi: 10.1175/2007JCLI1964.1

Helk, J. V., and Dunbar, M. (1953). Ice Islands: evidence from North Greenland. Arctic 6, 263-271. doi: 10.14430/arctic3881

Higgins, A. K. (1989). North Greenland ice islands. Polar Rec. 25, 207-212. doi: $10.1017 /$ S0032247400010809

Higgins, A. K. (1991). North Greenland Glacier Velocities and Calf Ice Production. (Bremerhaven: Alfred Wegener Institute for Polar and Marine Research \& German Society of Polar Research).

Holland, D. M., Thomas, R. H., de Young, B., Ribergaard, M. H., and Lyberth, B. (2008). Acceleration of Jakobshavn Isbræ triggered by warm subsurface ocean waters. Nat. Geosci. 1, 659-664. doi: 10.1038/ngeo316

Howat, I. M., and Eddy, A. (2011). Multi-decadal retreat of Greenland's marineterminating glaciers. J. Glaciol. 57, 389-396. doi: 10.3189/002214311796905631

Howat, I. M., Joughin, I., and Scambos, T. A. (2007). Rapid changes in ice discharge from Greenland outlet glaciers. Science 315, 1559-1561. doi: 10.1126/science. 1138478

Ignéczi, Á., Sole, A. J., Livingstone, S. J., Leeson, A. A., Fettweis, X., Selmes, N., et al. (2016). Northeast sector of the Greenland Ice Sheet to undergo the greatest inland expansion of supraglacial lakes during the 21st century. Geophys. Res. Lett. 43, 9729-9738. doi: 10.1002/2016GL070338

Jamieson, S. S. R., Vieli, A., Livingstone, S. J., Cofaigh, C. Ó., Stokes, C., Hillenbrand, C. D., et al. (2012). Ice-stream stability on a reverse bed slope. Nat. Geosci. 5, 799-802. doi: 10.1038/ngeo1600

Jenkins, A. (2011). Convection-driven melting near the grounding lines of ice shelves and tidewater glaciers. J. Phys. Oceanogr. 41, 2279-2294. doi: 10.1175/JPO-D-11-03.1

Jiskoot, H., Murray, T., and Luckman, A. (2003). Surge potential and drainage-basin characteristics in East Greenland. Ann. Glaciol. 36, 142-148. doi: 10.3189/172756403781816220

Johannessen, O. M., Babiker, M., and Miles, M. W. (2013). Unprecedented retreat in a 50-year observational record for Petermann Glacier, North Greenland. Atmos. Oceanic Sci. Lett. 6, 259-265. doi: 10.1080/16742834.2013.114 47091

Johnson, H. L., Münchow, A., Falkner, K. K., and Melling, H. (2011). Ocean circulation and properties in Petermann Fjord, Greenland. J. Geophys. Res. 116:C01003. doi: 10.1029/2010JC006519

Joughin, I., Abdalati, W., and Fahnestock, M. (2004). Large fluctuations in speed on Greenland's Jakobshavn Isbrae glacier. Nature 432, 608-610. doi: $10.1038 /$ nature03130

Joughin, I., Fahnestock, M., Kwok, R., Gogineni, P., and Allen, C. (1999). Ice flow of Humboldt, Petermann and Ryder Gletscher, northern Greenland. J. Glaciol. 45, 231-241. doi: 10.3189/002214399793377284

Joughin, I., Fahnestock, M., MacAyeal, D., Bamber, J. L., and Gogineni, P. (2001). Observation and analysis of ice flow in the largest Greenland ice stream. J. Geophys. Res. 106, 34021-34034. doi: 10.1029/2001JD900087

Joughin, I., Howat, I., Alley, R. B., Ekstrom, G., Fahnestock, M., Moon, T., et al. (2008a). Ice-front variation and tidewater behavior on Helheim and Kangerdlugssuaq Glaciers, Greenland. J. Geophys. Res. 113:F01004. doi: 10.1029/2007JF000837 
Joughin, I., Howat, I. M., Fahnestock, M., Smith, B., Krabill, W., Alley, R. B., et al. (2008b). Continued evolution of Jakobshavn Isbrae following its rapid speedup. J. Geophys. Res. 113:F04006. doi: 10.1029/2008JF001023

Joughin, I., Kwok, R., and Fahnestock, M. (1996a). Estimation of ice-sheet motion using satellite radar interferometry: method and error analysis with application to Humboldt Glacier, Greenland. J. Glaciol. 42, 564-575.

Joughin, I., Smith, B. E., Howat, I. M., Floricioiu, D., Alley, R. B., Truffer, M., et al. (2012). Seasonal to decadal scale variations in the surface velocity of Jakobshavn Isbrae, Greenland: observation and model-based analysis. J. Geophys. Res. 117:F02030. doi: 10.1029/2011JF002110

Joughin, I., Smith, B. E., Howat, I. M., Scambos, T., and Moon, T. (2010a). Greenland flow variability from ice-sheet-wide velocity mapping. J. Glaciol. 56, 415-430. doi: 10.3189/002214310792447734

Joughin, I., Smith, B. E., Howat, I. M., Scambos, T., and Moon, T. (2010b). MEaSUREs Greenland Ice Sheet Velocity Map from InSAR Data. Boulder, CO: National Snow and Ice Data Center. Digital media.

Joughin, I., Tulaczyk, S., Fahnestock, M., and Kwok, R. (1996b). A Mini-Surge on the Ryder Glacier, Greenland, Observed by Satellite Radar Interferometry. Science 274, 228-230.

Kamb, B., Raymond, C. F., Harrison, W. D., Engelhardt, H., Echelmeyer, K. A., Humphrey, N., et al. (1985). Glacier Surge Mechanism: 19821983 Surge of Variegated Glacier, Alaska. Science 227, 469-479. doi: $10.1126 /$ science. 227.4686 .469

Khan, S. A., Aschwanden, A., Bjørk, A. A., Wahr, J., Kjeldsen, K. K., and Kjær, K. H. (2015). Greenland Ice Sheet mass balance: a review. Rep. Prog. Phys. 78:046801. doi: 10.1088/0034-4885/78/4/046801

Khan, S. A., Kjær, K. H., Bevis, M., Bamber, J. L., Wahr, J., Kjeldsen, K. K., et al. (2014). Sustained mass loss of the northeast Greenland Ice Sheet triggered by regional warming. Nat. Clim. Chang. 4, 292-299. doi: 10.1038/nclimate2161

Koch, L. (1928). Contributions to the Glaciology of North Greenland. København: C.A. Reitzels.

Kollmeyer, R. C. (1980). West Greenland outlet glaciers: an inventory of the major iceberg producers. Cold Regions Sci. Technol. 1, 175-181. doi: 10.1016/0165-232X(80)90046-4

Layberry, R. L., and Bamber, J. L. (2001). A new ice thickness and bed data set for the Greenland ice sheet: 2. Relationship between dynamics and basal topography. J. Geophys. Res. Atmos. 106, 33781-33788. doi: 10.1029/2001JD900053

Mayer, C., Reeh, N., Jung-Rothenhäusler, F., Huybrechts, P., and Oerter, H. (2000). The subglacial cavity and implied dynamics under Nioghalvfjerdsfjorden Glacier, NE-Greenland. Geophys. Res. Lett. 27, 2289-2292. doi: 10.1029/2000GL011514

McFadden, E. M., Howat, I. M., Joughin, I., Smith, B. E., and Ahn, Y. (2011). Changes in the dynamics of marine terminating outlet glaciers in west Greenland (2000-2009). J. Geophys. Res. 116:F02022. doi: 10.1029/2010JF001757

Meier, M. F., and Post, A. (1969). What are glacier surges? Can. J. Earth Sci. 6, 807-817.

Meier, M., Lundstrom, S., Stone, D., Kamb, B., Engelhardt, H., Humphrey, N., et al. (1994). Mechanical and hydrologic basis for the rapid motion of a large tidewater glacier: 1. Observations. J. Geophys. Res. 99, 15219-15229. doi: $10.1029 / 94 \mathrm{jb} 00237$

Mernild, S. H., Liston, G. E., Hiemstra, C. A., and Christensen, J. H. (2010). Greenland Ice Sheet surface mass-balance modeling in a 131-Yr perspective, 1950-2080. J. Hydrometeorol. 11, 3-25. doi: 10.1175/2009JHM1140.1

Miles, B. W., Stokes, C. R., and Jamieson, S. S. (2016). Pan-ice-sheet glacier terminus change in East Antarctica reveals sensitivity of Wilkes Land to sea-ice changes. Sci. Adv. 2:e1501350. doi: 10.1126/sciadv.1501350

Mock, S. J. (1966). Fluctuations of the terminus of the Harald Moltke Bræ, Greenland. J. Glaciol. 6, 369-373.

Mohr, J. J., Reeh, N., and Madsen, S. N. (1998). Three-dimensional glacial flow and surface elevation measured with radar interferometry. Nature 391, 273-276. doi: $10.1038 / 34635$

Moon, T., and Joughin, I. (2008). Changes in ice front position on Greenland's outlet glaciers from 1992 to 2007. J. Geophys. Res. 113:F02022. doi: 10.1029/2007JF000927

Moon, T., Joughin, I., and Smith, B. (2015). Seasonal to multiyear variability of glacier surface velocity, terminus position, and sea ice/ice mélange in northwest
Greenland. J. Geophys. Res. Earth Surf. 120, 818-833. doi: 10.1002/2015jf0 03494

Moon, T., Joughin, I., Smith, B., and Howat, I. (2012). 21st-century evolution of Greenland outlet glacier velocities. Science 336, 576-578. doi: 10.1126/science.1219985

Morlighem, M., Rignot, E., Mouginot, J., Seroussi, H., and Larour, E. (2014). Deeply incised submarine glacial valleys beneath the Greenland Ice Sheet. Nat. Geosci. 7, 418-422. doi: 10.1038/ngeo2167

Morlighem, M., Rignot, E., Mouginot, J., Seroussi, H., and Larour, E. (2015). IceBridge BedMachine, Version 2. Boulder, CO: NASA National Snow and Ice Data Center Distributed Active Archive Center.

Motyka, R. J., Dryer, W. P., Amundson, J., Truffer, M., and Fahnestock, M. (2013). Rapid submarine melting driven by subglacial discharge, LeConte Glacier, Alaska. Geophys. Res. Lett. 40, 5153-5158. doi: 10.1002/grl.51011

Motyka, R. J., Hunter, L., Echelmeyer, K. A., and Connor, C. (2003). Submarine melting at the terminus of a temperate tidewater glacier, LeConte Glacier, Alaska, USA. Ann. Glaciol. 36, 57-65. doi: 10.3189/172756403781 816374

Motyka, R. J., Truffer, M., Fahnestock, M., Mortensen, J., Rysgaard, S., and Howat, I. (2011). Submarine melting of the 1985 Jakobshavn Isbrae floating tongue and the triggering of the current retreat. J. Geophys. Res. Earth Surf. 116:F01007. doi: 10.1029/2009JF001632

Mouginot, J., Rignot, E., Scheuchl, B., Fenty, I., Khazendar, A., Morlighem, M., et al. (2015). Fast retreat of Zachariæ Isstrøm, northeast Greenland. Science 350, 1357-1361. doi: 10.1126/science.aac7111

Münchow, A., Padman, L., and Fricker, H. A. (2014). Interannual changes of the floating ice shelf of Petermann Gletscher, North Greenland, from 2000 to 2012. J. Glaciol. 60, 489-499. doi: 10.3189/2014JoG13J135

Murray, T., Scharrer, K., Selmes, N., Booth, A. D., James, T. D., Bevan, S. L., et al. (2015). Extensive retreat of Greenland tidewater Glaciers, 2000-2010. Arct. Antarct. Alp. Res. 47, 427-447. doi: 10.1657/AAAR0014-049

Murray, T., Strozzi, T., Luckman, A., Jiskoot, H., and Christakos, P. (2003). Is there a single surge mechanism? Contrasts in dynamics between glacier surges in Svalbard and other regions. J. Geophys. Res. Solid Earth 108:2237. doi: 10.1029/2002JB001906

Nick, F. M., Luckman, A., Vieli, A., van der Veen, C. J., Van As, D., Van De Wal, R. S. W., et al. (2012). The response of Petermann Glacier, Greenland, to large calving events, and its future stability in the context of atmospheric and oceanic warming. J. Glaciol. 58, 229-239. doi: 10.3189/2012JoG11J242

Nick, F. M., Vieli, A., Andersen, M. L., Joughin, I., Payne, A., Edwards, T. L., et al. (2013). Future sea-level rise from Greenland's main outlet glaciers in a warming climate. Nature 497, 235-238. doi: 10.1038/nature12068

Nick, F. M., Vieli, A., Howat, I. M., and Joughin, I. (2009). Large-scale changes in Greenland outlet glacier dynamics triggered at the terminus. Nat. Geosci. 2, 110-114. doi: 10.1038/ngeo394

Palmer, S., Shepherd, A., Nienow, P., and Joughin, I. (2011). Seasonal speedup of the Greenland Ice Sheet linked to routing of surface water. Earth Planet. Sci. Lett. 302, 423-428. doi: 10.1016/j.epsl.2010.12.037

Peary, R. E. (1892). The North Greenland Expedition of 1891-92. J. Am. Geogr. Soc. N.Y. 24, 536-538. doi: 10.2307/196713

Pimentel, S., and Flowers, G. E. (2010). A numerical study of hydrologically driven glacier dynamics and subglacial flooding. Proc. R. Soc. A 467, 537-558. doi: 10.1098/rspa.2010.0211

Podrasky, D., Truffer, M., Fahnestock, M., Amundson, J. M., Cassotto, R., and Joughin, I. (2012). Outlet glacier response to forcing over hourly to interannual timescales, Jakobshavn Isbræ, Greenland. J. Glaciol. 58, 1212-1226. doi: 10.3189/2012JoG12J065

Porter, D. F., Tinto, K. J., Boghosian, A., Cochran, J. R., Bell, R. E., Manizade, S. S., et al. (2014). Bathymetric control of tidewater glacier mass loss in northwest Greenland. Earth Planet. Sci. Lett. 401, 40-46. doi: 10.1016/j.epsl.2014.05.058

Pritchard, H., Murray, T., Luckman, A., Strozzi, T., and Barr, S. (2005). Glacier surge dynamics of Sortebræ, east Greenland, from synthetic aperture radar feature tracking. J. Geophys. Res. 110:F03005. doi: 10.1029/2004JF000233

Rasmussen, K. (1919). The second thule expedition to Northern Greenland, 1916-1918. Geogr. Rev. 8, 116-125. doi: 10.2307/207633

Rasmussen, K. J. V. (1912). Report of the First Thule Expedition 1912. København: CA Reitzels Forlag.

Raymond, C. (1996). Shear margins in glaciers and ice sheets. J. Glaciol. 42, 90-102. 
Reeh, N., Bøggild, C. E., and Oerter, H. (1994). Surge of Storstrømmen, a large oulet glacier from the Inland Ice of North-East Greenland. Grønlands Geologiske Undersogelse Rapport 162, 201-209.

Reeh, N., Mayer, C., Miller, H., Thomsen, H. H., and Weidick, A. (1999). Present and past climate control on fjord glaciations in Greenland: implications for IRD-deposition in the sea. Geophys. Res. Lett. 26, 1039-1042. doi: 10.1029/1999GL900065

Reeh, N., Mohr, J. J., Nørvang Madsen, S., Oerter, H., and Gundestrup, N. S. (2003). Three-dimensional surface velocities of Storstrømmen glacier, Greenland, derived from radar interferometry and ice-sounding radar measurements. J. Glaciol. 49, 201-209. doi: 10.3189/172756503781830818

Reeh, N., Thomsen, H. H., Higgins, A. K., and Weidick, A. (2001). Sea ice and the stability of north and northeast Greenland floating glaciers. Ann. Glaciol. 33, 474-480. doi: 10.3189/172756401781818554

Rignot, E. (1996). Tidal flexure, ice velocities, and ablation rates of petermann gletscher, Greenland. J. Glaciol. 42, 476-485.

Rignot, E., Gogineni, S., Joughin, I., and Krabill, W. (2001). Contribution to the glaciology of northern Greenland from satellite radar interferometry. J. Geophys. Res. 106, 34007. doi: 10.1029/2001JD900071

Rignot, E., Gogineni, S. P., Krabill, W., and Ekholm, S. (1997). North and Northeast Greenland Ice discharge from satellite radar interferometry. Science 276, 934-937. doi: 10.1126/science.276.5314.934

Rignot, E., and Kanagaratnam, P. (2006). Changes in the velocity structure of the Greenland Ice Sheet. Science 311, 986-990. doi: 10.1126/science. 1121381

Rignot, E., and Steffen, K. (2008). Channelized bottom melting and stability of floating ice shelves. Geophys. Res. Lett. 35:L02503. doi: 10.1029/2007GL031765

Scambos, T. A. (2004). Glacier acceleration and thinning after ice shelf collapse in the Larsen B embayment, Antarctica. Geophys. Res. Lett. 31:L18402. doi: 10.1029/2004GL020670

Sciascia, R., Straneo, F., Cenedese, C., and Heimbach, P. (2013). Seasonal variability of submarine melt rate and circulation in an East Greenland fjord. J. Geophys. Res. Oceans 118, 2492-2506. doi: 10.1002/jgrc.20142

Seale, A., Christoffersen, P., Mugford, R. I., and O'Leary, M. (2011). Ocean forcing of the Greenland Ice Sheet: calving fronts and patterns of retreat identified by automatic satellite monitoring of eastern outlet glaciers. J. Geophys. Res. 116:F03013. doi: 10.1029/2010JF001847

Sharp, M. (1988). Surging glaciers: behaviour and mechanisms. Prog. Phys. Geogr. 12, 349-370. doi: $10.1177 / 030913338801200302$

Shepherd, A., Ivins, E. R., Geruo, A., Barletta, V. R., Bentley, M. J., Bettadpur, S., et al. (2012). A reconciled estimate of ice-sheet mass balance. Science 338, 1183-1189. doi: $10.1126 /$ science. 1228102

Shreve, R. (1972). Movement of water in glaciers. J. Glaciol. 11, 205-214.

Sohn, H.-G., Jezek, K. C., and van der Veen, C. J. (1998). Jakobshavn Glacier, west Greenland: 30 years of spaceborne observations. Geophys. Res. Lett. 25, 2699-2702. doi: 10.1029/98GL01973

Sole, A., Nienow, P., Bartholomew, I., Mair, D., Cowton, T., Tedstone, A., et al. (2013). Winter motion mediates dynamic response of the Greenland Ice Sheet to warmer summers. Geophys. Res. Lett. 40, 3940-3944. doi: 10.1002/grl.50764

Tedesco, M., Mote, T., Fettweis, X., Hanna, E., Jeyaratnam, J., Booth, J. F., et al. (2016). Arctic cut-off high drives the poleward shift of a new Greenland melting record. Nat. Commun. 7:11723. doi: 10.1038/ncomms11723
Tedstone, A. J., Nienow, P. W., Gourmelen, N., Dehecq, A., Goldberg, D., and Hanna, E. (2015). Decadal slowdown of a land-terminating sector of the Greenland Ice Sheet despite warming. Nature 526, 692-695. doi: 10.1038/nature15722

Thomas, R., Frederick, E., Krabill, W., Manizade, S., and Martin, C. (2009). Recent changes on Greenland outlet glaciers. J. Glaciol. 55, 147-162. doi: $10.3189 / 002214309788608958$

Thomsen, H. H., Reeh, N., Olesen, O. B., Boggild, C. E., Starzer, W., Weidick, A., et al. (1997). The Nioghalvfjerdsfjorden glacier project, North-East Greenland: a study of ice sheet response to climatic change. Geol. Surv. Denmark Greenland 176, 95-103.

van den Broeke, M., Bamber, J., Ettema, J., Rignot, E., Schrama, E., van de Berg, W. J., et al. (2009). Partitioning recent Greenland mass loss. Science 326, 984-986. doi: $10.1126 /$ science. 1178176

van den Broeke, M. R., Enderlin, E. M., Howat, I. M., Kuipers Munneke, P., Noël, B. P. Y., van de Berg, W. J., et al. (2016). On the recent contribution of the Greenland Ice Sheet to sea level change. Cryosphere 10, 1933-1946. doi: 10.5194/tc-10-1933-2016

van der Veen, C. J. (1998). Fracture mechanics approach to penetration of surface crevasses on glaciers. Cold Regions Sci. Technol. 27, 31-47. doi: 10.1016/S0165-232X(97)00022-0

van der Veen, C. J. (2007). Fracture propagation as means of rapidly transferring surface meltwater to the base of glaciers. Geophys. Res. Lett. 34:L01501. doi: 10.1029/2006GL028385

Walter, F., Chaput, J., and Luthi, M. P. (2014). Thick sediments beneath Greenland's ablation zone and their potential role in future ice sheet dynamics. Geology 42, 487-490. doi: 10.1130/G35492.1

Warren, C. R., and Glasser, N. F. (1992). Contrasting Response of South Greenland Glaciers to Recent Climatic Change. Arctic Alpine Res. 24, 124-132. doi: $10.2307 / 1551532$

Weidick, A., Williams, R. S., and Ferrigno, J. G. (1995). Satellite Image Atlas of Glaciers of the World. Washington, DC: US Government Printing Office.

Wright, J. W. (1939). Contributions to the Glaciology of North-West Greenland. København: C.A. Reitzel.

Xu, Y., Rignot, E., Menemenlis, D., and Koppes, M. (2012). Numerical experiments on subaqueous melting of Greenland tidewater glaciers in response to ocean warming and enhanced subglacial discharge. Ann. Glaciol. 53, 229-234. doi: 10.3189/2012AoG60A139

Zwally, H. J., Abdalati, W., Herring, T., Larson, K., Saba, J., and Steffen, K. (2002). Surface melt-induced acceleration of Greenland ice-sheet flow. Science 297, 218-222. doi: $10.1126 /$ science. 1072708

Conflict of Interest Statement: The authors declare that the research was conducted in the absence of any commercial or financial relationships that could be construed as a potential conflict of interest.

Copyright $\odot 2017$ Hill, Carr and Stokes. This is an open-access article distributed under the terms of the Creative Commons Attribution License (CC BY). The use, distribution or reproduction in other forums is permitted, provided the original author(s) or licensor are credited and that the original publication in this journal is cited, in accordance with accepted academic practice. No use, distribution or reproduction is permitted which does not comply with these terms. 